\section{Deployment of whistleblowing as an accountability mechanism to curb corruption and fraud in a developing democracy}

Whistleblowing to curb corruption and fraud

Oliver Nnamdi Okafor

Ted Rogers School of Management, Ryerson University, Toronto, Canada

Festus A. Adebisi

Southern Alberta Institute of Technology, Calgary, Canada

Michael Opara

College of Business, Texas A\&M University, Commerce, Texas, USA, and

Chidinma Blessing Okafor

Numeris, Toronto, Canada
Received 22 December 2018

Revised 18 June 2019

23 November 2019

3 March 2020

Accepted 11 March 2020

\begin{abstract}
Purpose - This paper investigates the challenges and opportunities for the deployment of whistleblowing as an accountability mechanism to curb corruption and fraud in a developing country. Nigeria is the institutional setting for the study.

Design/methodology/approach - Adopting an institutional theory perspective and a survey protocol of urban residents in the country, the study presents evidence on the whistleblowing program introduced in 2016. Nigeria's whistleblowing initiative targets all types of corruption, including corporate fraud.

Findings - This study finds that, even in the context of a developing country, whistleblowing is supported as an accountability mechanism, but the intervention lacks awareness, presents a high risk to whistleblowers and regulators, including the risk of physical elimination, and is fraught with institutional and operational challenges. In effect, awareness of whistleblowing laws, operational challenges and an institutional environment conducive to venality undermine the efficacy of whistleblowing in Nigeria.

Originality/value - The study presents a model of challenges and opportunities for whistleblowing in a developing democracy. The authors argue that the existence of a weak and complex institutional environment and the failure of program institutionalization explain those challenges and opportunities. The authors also argue that a culturally anchored and institutionalized whistleblowing program encourages positive civic behavior by incentivizing citizens to act as custodians of their resources, and it gives voice to the voiceless who have endured decades of severe hardship and loss of dignity due to corruption.
\end{abstract}

Keywords Whistleblowing, Institutional theory, Corruption and fraud, Corruption in Nigeria

Paper type Research paper

\section{Introduction}

Developing countries, particularly in Africa, consistently receive deplorable global rankings pertaining to corruption and fraud. For example, on both the 2017 and 2018 Corruption Perception Index (CPI) reports, only eight out of 49 Sub-Saharan African countries had corruption perception scores above the global average (Transparency International, 2018, 2019). Yet, studies on the use of whistleblowing to combat corruption and fraud have focused on

(C) Oliver Nnamdi Okafor, Festus A. Adebisi, Michael Opara and Chidinma Blessing Okafor. Published by Emerald Publishing Limited. This article is published under the Creative Commons Attribution (CC BY 4.0) licence. Anyone may reproduce, distribute, translate and create derivative works of this article (for both commercial and non-commercial purposes), subject to full attribution to the original publication and authors. The full terms of this licence may be seen at http://creativecommons.org/licences/by/4.0/ legalcode 
AAAJ 33,6

1336

developed countries and not on African and other developing countries(e.g. Dworkin and Baucus, 1998; Nielsen, 2013; Cordis and Lambert, 2017). This lack of interest is consistent with the general pattern of scant research on accounting and accountability in Africa documented in the literature (e.g. Rahaman, 2010; MainaWaweru et al.,2004). This is in spite of the need for methods to combat major issues such as: "historically-embedded cultural and political relations" (Harrison, 2005, p. 240), extensive and intensive bribery (Lavallée and Roubaud, 2019), and pervasive corruption that constrains economic development in Africa (Mbaku, 2016), coupled with the "youth and inexperience" of African countries in the implementation of whistleblowing programs. Nyamori et al. (2017) suggest that Africa provides immense opportunities for empirical accounting research on anticorruption intervention. In this study, we investigate the challenges and opportunities for the deployment of whistleblowing as an accountability mechanism (Foegle, 2015) to curb corruption and fraud ina developing democracy using a survey. The study focuses on Nigeria, which is a developing country with a complex institutional environment and an unenviable record as highly corrupt - ranking 148 of 180 in the 2017 CPI report (Transparency International, 2018). Thus, Nigeria's whistleblowing program offers a rich institutional context for examining the challenges and opportunities for whistleblowing.

Nielsen (2013, p. 385) investigates whistleblowing for reforming regulatory institutions and outlines four major institutional obstacles to effective whistleblowing: (1) Whistleblowing regulatory institutions are "often systematically understaffed," and they lack the resources to adequately process reported cases. (2) Regulators responsible for processing whistleblowing cases are "often systematically inexperienced." (3) Regulators are "often under systemic pressure from the politicians who appoint them to ignore whistle-blowing cases relevant to their sources of financial and/or ideological political support." (4) Whistleblowers face "high systemic risks". Nielsen's (2013) suggestions are hinged on a qualitative analysis of regulatory issues and events that mostly occurred in the USA. Our study draws on Nielsen's (2013) suggestions and deploys the institutional theory to understand and analyze opinions of a purposive sample of Nigerian residents on a whistleblowing intervention instituted in the country to reduce corruption and fraud, on the premise that the institutional and cultural environment contexts are in need of reform. This repositioning to attain a new normal that will help rid the country of corruption is in line with Davies' (2001, p. 74) suggestion that "a fair and effective mechanism of accountability is a fruitful source of norms". This study leads to a deeper and more nuanced understanding of whistleblowing because, at the extreme, the challenges and opportunities for deployment of whistleblowing may be systemically different between developed and developing countries, or, at a minimum, additional institutional and/or operational issues experienced by a developing country may emerge.

Researchers have garnered evidence on whistleblowing from various stakeholders, including whistleblowers (e.g. Park et al., 2018; Terry and Baucus, 1998), public service employees (Mbago et al., 2018), auditors/accountants (Latan et al., 2018; Alleyne et al., 2013; Brennan and Kelly, 2007) and students (Liyanarachchi and Newdick, 2009) to investigate challenges and opportunities for whistleblowing. However, the general perception of whistleblowing as an accountability mechanism in developing countries has not received considerable attention in academic research. This paper focuses on whistleblowing program awareness, relevance, performance and obstacles, to identify the challenges and opportunities of this anti-corruption intervention introduced in Nigeria. The paper presents an early evidence, given that Nigeria instituted a nationwide whistleblowing intervention in 2016 to combat pervasive corruption and fraud, and hold its politicians, public officers, corporate executives and citizens accountable. The paper further analyzes respondents' opinions by demographic characteristics to explore whether there are differences in the attributes of respondents.

Our paper adopts an institutional theory perspective to present a model of challenges and opportunities for whistleblowing in Nigeria. Institutional theory (DiMaggio and Powell, 1983; 
Scott, 2014; Kreander and McPhail, 2019) is relevant for this study as it focuses on the effects of the institutional environment in motivating organizational action. With its emphasis on the social context that organizations are embedded in, the institutional theory presents a lens to analyze responses to the challenges associated with the institutional environment. As institutional theory builds on a social constructivist world view (Modell et al., 2017; Opara and Rouse, 2019), it considers institutions as social constructs (DiMaggio and Powell, 1983). Moreover, recent strands of the institutional theory point to the relevance of institutional work (Lawrence and Suddaby, 2006) and conflicting institutional logics in empowering actors to change their institutional environment (Reay and Hinings, 2009; Greenwood et al., 2011). In Nigeria, there are communal logic (kinship public) and legal logic (civic public) that appear to be in conflicts (Ekeh, 1975). We consider the implementation of a whistleblowing program as a mechanism of accountability by a governmentelected on the promise to curb corruption, and an attempt by anticorruption actors to influence their institutional environment to combat corruption in Nigeria (Foegle, 2015).

This study finds that Nigerians support the whistleblowing intervention, but the intervention lacks general public awareness, presents a high risk to whistleblowers and regulators, including the risk of physical danger, and is fraught with operational and institutional challenges, consistent with Ayamba's (2019) suggestions. This paper proposes that inability to institutionalize the intervention program, coupled with a weak and complex institutional environment in Nigeria, undermine the effectiveness of whistleblowing. Our paper suggests that in a developing country context, whistleblowing has a key role to play as an accountability tool in fighting corruption, as it provides a bottom-line assessment that targets corruption, recoups stolen funds and institutes effective control over public and corporate resources. The findings suggest that the use of whistleblowing as an accountability mechanism encourages positive citizenship behavior because whistleblowers are incentivized to act as custodians of their own resources. Whistleblowing also gives voice to the voiceless who have endured the adverse impacts of corruption through their lived experiences (Everett et al., 2007). In effect, the challenges and opportunities identified in this paper may help to mitigate conflicting logics, strengthen accountability institutions and promote effective regulations and programs to curb corruption and fraud in Nigeria, consistent with the United Nations Sustainable Goal 16. However, for the program to be successful, Nigeria must use her cultural leverage to institutionalize the intervention.

The remaining parts of this paper are presented as follows. Section 2 presents a review of related literature on whistleblowing and corruption, including the pervasiveness of corruption and fraud in Nigeria. Section 3 discusses the theoretical background. Section 4 describes the research methodology. Section 5 outlines the findings and presents an analysis of citizens' opinions. The study concludes with a discussion of the findings in Section 6.

\section{Literature review}

\subsection{Whistleblowing: nature and context}

There are no generally agreed definitions of whistleblowing. The term whistleblowing could be seen as an act of dissent (Dungan et al., 2015; Elliston, 1982) or defined more precisely as "an open disclosure about significant wrongdoing made by a concerned citizen totally or predominantly motivated by notions of public interest" (De Maria, 1995, p. 447). According to Dungan et al. (2015), two perspectives seem to persist in the conversation around whistleblowing. The first views whistleblowing as an act of justice, serving or intending to right a wrong, such as the case of former WorldCom's Cynthia Cooper (Dungan et al., 2015; Seifert et al., 2010). Maroun and Solomon (2014) suggest that the perceived transparency gained from whistleblowing and the contention that whistleblowing is in the public interest provide practical and moral legitimacy. Essentially, whistleblowing "may be perceived as an effective response to the failure of the state to develop adequate public accountability 
AAAJ 33,6

mechanisms" (Alleyne et al., 2013, p. 11). Whistleblowers would be seen as active participants in the search for economic and social justice (Bougen et al., 1999). Intending to right a wrong, the potential whistleblower may set out to correct a malpractice or malfeasance. The second view considers whistleblowing as a breach, disloyalty or a form of betrayal. In this regard, whistleblowers are the target of retaliation and tend to face considerable backlash from friends and foes. Elliston (1982) evaluates whistleblowing and civil disobedience as two forms of dissent and notes that a logical argument to justify both forms of dissent is to argue that principles of justice take precedence over obligation to keep promises.

Near and Miceli (1996) identify three elements that are required for whistleblowing to occur: (1) a wrongdoer who commits the alleged wrongdoing; (2) a whistleblower who observes the wrongdoing, defines it as such and reports it; and (3) the recipient of the wrongdoing report. While researchers have focused considerable attention on understanding and measuring whistleblowing behavior (Miceli et al., 2012), it remains challenging to successfully do so in practice. Miceli and Near (1988) link the challenge to associated ethical and situational characteristics of whistleblowing.

A major challenge to whistleblowing is the identification and adoption of relevant enabling conditions that promote whistleblowing and discourage retaliation all at once (Alleyne et al., 2013; Reckers-Sauciuc and Lowe, 2010). Alleyne et al. (2013) draw on both justice theory and institutional theory to suggest that individual factors directly influence whistleblowing intentions, but isomorphic and issue-specific factors moderate the effects. Near et al. (1993) also rely on justice theory in addition to the power theory to explain whistleblowing processes. Their study suggests that it is legalistic mechanisms used by organizations that encourage whistleblowing, not legal procedures.

While a bulk of the literature on whistleblowing has focused on developed countries, a few studies have examined whistleblowing challenges and opportunities in developing countries Maroun and Atkins (2014) examine whistleblowing by external auditors in South Africa and find that mandating external auditors to blow the whistle on irregularities will not only make more information available to stakeholders, it would increase "transparency and accountability". Studies conducted in both developed and developing countries suggest that regulators generally navigate challenging institutional terrains in the deployment of whistleblowing as an accountability mechanism (see Suyatno et al., 2015). Consistent with Bakre et al. (2017), we argue that regulators in developing countries operate in a more complex environment due to weak institutional structures and a cultural context that is tolerant of or receptive to corruption.

The construction and legitimization of whistleblowing as a socially acceptable fraud disclosure mechanism has gained prominence since the escalation in corporate malfeasance in the new century (Stolowy et al., 2019). Many countries have enacted or pledged to enact whistleblower legislation (Transparency International, 2013). We argue that while the public perception of whistleblowers remains fragile, the convergence of these legislations and social events have strengthened the acceptance of whistleblowing as a viable accountability mechanism for combating corruption and fraud.

\subsection{Corruption and organizational culture}

Corruption and fraud embody a spectrum of illegal payments and transactions such as bribes, embezzlement and money laundering, among others. Corruption is the abuse or misuse of entrusted power or public office for private gain (Everett et al., 2007). A PricewaterhouseCoopers (2016) report indicates that corruption is associated with a longterm capacity of a country to achieve its potential, and has noxious effects, including a longrun negative impact on growth through the reduction in human capital and investment, low tax revenue and expenditure GDP ratio, poor public finance management, poor provision of 
public goods, erosion of talent in public institutions, low overall investment due to lack of investor confidence, and higher prices and barriers to entry for businesses. Corruption is and remains a global phenomenon, affecting both developing and developed economies. The United Nations estimates that "corruption, bribery, theft and tax evasion cost some US $\$ 1.26$ trillion for developing countries per year" (United Nations, 2019).

While the support and acceptance of anticorruption measures have continued to rise in policymaking arenas, researchers have focused on organizational culture, structure and cognition to understand the existence of corruption (e.g. Alleyne et al., 2018). Lee and Xiao (2018) document that organizational infrastructure is organized in several ways to handle corruption and fraud. Mannion et al. (2018, p. 26) add that this "internal context" is "influenced by the deliberate actions of key members of the organization, and include an organization's culture and climate, education and training, peer pressure and relationships, leadership and management". The nature and impact of leadership and management enable or constrain a culture of corruption, and they affect the effectiveness of anticorruption measures (Kaptein, 2011). Culiberg and Mihelic (2017) suggest that ethical leadership and management can motivate a culture of whistleblowing in an organization.

\subsection{Corruption and fraud in Nigeria}

Corruption and lack of accountability have been endemic in sub-Saharan Africa (Grindle, 2004; Rahaman, 2009), and Nigeria in particular. The World Bank (2017) considers corruption a priority problem and reports that an audit of the oil sector in Nigeria uncovered outstanding recoverable revenue of $\$ 9.8$ bn between 1999 and 2008. Hoffmann and Patel (2017, p. 1) document that "close to $\$ 400 \mathrm{bn}$ was stolen from Nigeria's public accounts from 1960 to 1999" and between 2005 and 2014, some $\$ 182$ bn was lost from the country through illicit financial flows.

Researchers have attempted to understand the root causes of corruption in Nigeria. According to Agbiboa (2012), the emergence and intensification of corruption in Nigeria can be traced to prolonged military involvement in the political space that essentially legitimized corruption. Furthermore, the abandonment of a basic culture of probity and accountability ruined the public sector to the extent that even the promised paltry salaries were not paid for several months at a time, thereby predisposing public servants to find alternative means of survival. This is further compounded by the absence of alternative opportunities outside the public sector. Agbiboa insists that the Nigerian culture of condoning and celebrating corruption only when it is perpetrated by a son-of-the-soil (tribal son/kinsman) is at the root of Nigeria's corruption (see also Okafor et al., 2020). Bakre and Lauwo (2016) add that "a crony socio-political system and culture of impunity" (p. 49) perpetuate corruption in Nigeria. In examining corruption in Africa, Ekeh (1975) theorizes the existence of two publics: a moral kinship public- rooted in kin-group and community of origin, and an amoral civic publicimposed under colonialism and adopted by indigenous postcolonial administrations.

Nigeria's long history of widespread corruption (Ayamba, 2019) has been the subject of extensive policy interventions. Successive Nigerian governments have attempted several accountability measures, including institutional reforms that introduced judicial and investigative agencies [1], and several administrative and judicial panels of enquiry (Ogungbamila, 2014; Ijewereme, 2015). Similarly, legislative enactments were initiated with limited results. These disappointing results extended to financial accounting and accountability reforms promoted by international financial institutions. Bakre et al. (2017) conclude that the adoption of the International Public Sector Accounting Standards (IPSASs) in the public sector was unsuccessful in Nigeria due to a weak regulatory environment and poor state institutions. The authors argue that Western accounting reforms failed in Nigeria because the reforms did not reflect the country's social, political, economic and cultural 
AAAJ 33,6

1340

environment. Thus, these prior regulatory, institutional and legislative reforms generally proved inadequate for tackling corruption and fraud in Nigeria.

Ordinary citizens require a set of accountability mechanisms to empower them to bring change and justice against dominant political and corporate actors who benefit from proceeds of corruption. Denedo et al. (2017) find that NGOs effectively used counter accountability as part of a composite of campaign measures to address power imbalance, reform government institutions and change corporate practices in Nigeria. Counter accountability seeks to induce change by giving voice to the oppressed and challenging the dominant power structure, unacceptable political behavior and irresponsible corporate practices (Everett, 2004; Denedo et al., 2017). Thus, research suggests that counter accountability can be effective in Nigeria in its own right. While NGOs have played a major role in promoting accountability in Nigeria (Denedo et al., 2017; Hoffmann and Patel, 2017), they have also contributed to corruption in the country (Smith, 2010).

A new government in 2015 in Nigeria catalyzed another attempt to mobilize the citizens to tackle corruption once again via a whistleblowing program (Ayamba, 2019). The promise to tackle corruption made during the 2015 presidential election campaign culminated in the establishment of a whistleblowing program in 2016. Whistleblowers may receive between 2.5 and $5 \%$ of recovered amount as a financial incentive (Ministry of Finance, 2016). To protect whistleblowers and witnesses, the Nigerian Senate passed the Witness Protection Program (Establishment, etc.) Act, 2017 (Federal Republic of Nigeria National Assembly, 2017). Hoffmann and Patel (2017, p. 4) suggest that Nigeria's fight against corruption using "traditional legal and governance based measures" needs to change. Our view is that the outcome of various reform efforts over the years has not been successful. Therefore, while the emphasis on transparency and legal approach remains critically important, innovative complementary approaches are needed to foster a shift in the renewed effort to fight corruption in Nigeria.

\section{Theoretical background}

\subsection{Corruption and fraud: an institutional theory perspective}

For decades, the principal-agent (P-A) economic model has provided the theoretical basis for much of the research on corruption and has informed the design and implementation of most contemporary accountability initiatives (Rothstein, 2011). In a 2011 metaanalysis of 115 studies examining corruption's impacts on economic growth, Ugur and Dasgupta (2011, p. 43) found that every study "adhered to an explicitly stated principal-agent approach to corruption" or was "closely related to that approach". Kinder and Sears (1985) further indicate that theories of public opinion have their origins in a rational choice perspective motivated by a self-interest logic emanating from economics, finance and political science. The rational choice theory assumes people understand their self-interests and form opinions to support or oppose policies based on a self-serving bias (Rhodes et al., 2017; Shwom et al., 2010). While the rational choice view has persisted, researchers now increasingly acknowledge the relevance of social context, which includes a variety of social factors and forces in the environment (Shwom et al., 2010). This alternative cultural approach suggests that actors construct discourses, frames or storylines that appropriate competing knowledge domains by engaging core values and generalized beliefs about the world (Dietz et al., 1998).

Misangyi et al.'s (2008, p. 750) theorizing suggests that the economic perspective, including the roles of rational self-interested actors and "formal regulative structures" in combating corruption, have produced limited results. They argue that it is the interaction of institutional logics, social actors and available resources that ultimately determine the effectiveness of remedies for corruption. While our study recognizes the dominance of the P-A model, and the relevance of the cultural perspective to combatting corruption and fraud, we 
argue that given the Nigerian context and institutional environment, an institutional theoretical approach would be more relevant and appropriate. While early theorists viewed formal organizations as bounded and self-contained entities that occasionally engaged with their environment, institutional theory considers formal organizations to be embedded in their institutional environment rather than simply occasionally interacting with them (Meyer and Rowan, 1977; Tolbert and Zucker, 1996).

Luo (2005) investigates the persistence of corruption despite the introduction of anticorruption policy measures and theorizes that institutional opaqueness, injustice and complexity shape corruption while culture, structure and compliance systems determine the effectiveness of anticorruption initiatives. Sulu-Gambari et al. (2018) draw on institutional theory and evidence from a Nigerian ministry to suggest that political and economic environments can affect accountability reform in an unpredictable and nonlinear manner. Institutional theory has been applied to the study of corruption in several other institutional contexts, including the study by Pillay and Kluvers (2014) that examines the nature and implications of corruption in South Africa's public sector and a recent study by Kreander and McPhail (2019) on the use of Council of Ethics as an accountability mechanism in Norway. These studies demonstrate that institutional theory is a valid theoretical lens. Therefore, we frame this study on an institutional theory perspective to assess an attempt at corruption eradication in the country.

Institutional theory has also been applied to understand and explain organizational behavior such as its management practices, organizational structuring and administrative measures and responses to other organizational field participants (Dacin et al., 2002; Scott, 2014). However, recent strands of institutional theory, such as institutional work, have focused on the reverse process - how actors, through their intentional activities, impact institutions under which they operate (Lawrence and Suddaby, 2006; see also Lawrence et al., 2009). According to Lawrence and Suddaby (2006, p. 215), institutional work is "the purposive action of individuals and organizations aimed at creating, maintaining and disrupting institutions". This shift in emphasis has meant greater attention devoted to understanding how individuals in their regular work activities affect the emergence, sustenance and displacement of institutions to achieve desired outcomes. This has meant a focus on understanding the role of agency in organizational change. Furthermore, change actors draw on institutional theory's concept of institutional logics advanced by Thornton and Ocasio (2008), and Thornton et al. (2012).

Thornton and Ocasio (2008, p. 101) define institutional logics as "the socially constructed, historical patterns of material practices, assumptions, values, beliefs, and rules by which individuals produce and reproduce their material subsistence, organize time and space, and provide meaning to their social realities". Importantly, institutional logics are implicated in shaping how specific social actors construct and reconstruct their institutional existence. It recognizes the role of human agency and provides them with a repertoire of logics they can mobilize to advance their interests, effect organizational change and enact a new institutional environment. Institutional theorists point to the concept of conflicting/ contradictory logics, that can lead to institutional complexity (Kreander and McPhail, 2019; McPherson and Sauder, 2013), and these logics are relevant in understanding social and organizational responses (Smith and Tracey, 2016; Greenwood et al., 2011). We argue that conflicting logics arising from an on-going struggle for dominance between civic and communal logics have persisted in Nigeria's postcolonial institutional environment (Ekeh, 1975). The conflicting logics, in our view, are a source of Nigeria's institutional complexity. Therefore, we consider Nigeria as beset by several contradictions that have led to institutional, structural and governance complexities; and we interpret the actions of the $\mathrm{EFCC}$ as an attempt to enact a new institutional environment using whistleblowing as an accountability mechanism. 
AAAJ 33,6

1342

When corruption is encouraged by the wider institutional environment, the support for accountability mechanisms becomes the exception rather than the norm; and in the absence of the political will to eliminate corruption, collective societal progress stalls (Luo, 2005). In essence, the various dimensions of corruption are a result of the social context of institutions that shape their actions (Pillay and Kluvers, 2014). A central plank of institutional theory is legitimacy (Deephouse et al., 2017), in which organizations seek compliance with their institutional environment in their effort to be perceived as modern, attract resources to themselves and justify their existence. Therefore, actions that conflict with this institutional image represents an existential threat to the organization.

Consistent with Scott (2014), this paper argues that the informal rules and regulations of society are closely linked to a society's culture, subcultures and history (Ekeh, 1975). Therefore, these informal rules and regulations shape the visible and invisible behavior of the society - suggesting acceptable norms, roles and behaviors. Essentially, societal behavior is anchored on its accepted social institutions and the general socio-cultural context. To improve the effectiveness of the whistleblowing intervention, regulators must understand the underlying cultural dimensions (MacNab et al., 2007), adapt whistleblowing policies to their organizational cultures (Loyens, 2013) and increase legitimacy by building and sustaining trust relationships (Aldrich and Fiol, 1994). Since institutional factors affect the effectiveness of whistleblowing (Nielsen, 2013), the introduction of a whistleblowing law as an accountability mechanism to combat corruption stands little chance of success where the implicit and explicit values and norms supporting corruption are promoted by "powerful individuals" who are perceived to be entrenched in society. An effective whistleblowing accountability mechanism must tackle and assail these powerful institutional forces and establish a new institutional environment that is conducive to low corruption (Lawrence and Suddaby, 2006; Lawrence et al., 2009). Regulators must muddle through, learn by doing, be creative and adapt their intervention incrementally to increase legitimacy and institutionalize the intervention (Deephouse et al., 2017; Zucker, 1983). This paper argues that the whistleblowing intervention introduced in Nigeria must be institutionalized in order to become an effective accountability mechanism.

\subsection{Constructing whistleblowing as an accountability mechanism}

In an environment of endemic corruption and fraud, loss of faith in government and crisis of legitimacy in the civic public (Ekeh, 1975), Nigeria's whistleblowing initiative is an attempt to decouple the anticorruption (organizational) infrastructure from the rest of government, build a special relationship with stakeholders and erect a new accountability framework using the instrumentality of the nascent whistleblowing program (Ayamba, 2019). We draw on institutional theory concepts of legitimacy, institutional work and institutional logics (Deephouse et al., 2017; Greenwood et al., 2011) to enable us to understand the interplay between the institutional, cultural and social underpinnings of corruption. We further draw on the study by Kreander and McPhail (2019) to investigate whistleblowing as an accountability mechanism. In their study involving state investments and human rights, these authors explore the Council of Ethics in Norway as a new accountability mechanism.

To understand whistleblowing as an accountability mechanism (Foegle, 2015) from an institutional perspective given Nigeria's context, we need to revisit Ekeh (1975) as our starting point. Ekeh postulates that postcolonial African society is structurally trapped in a dual character consisting of a primordial kinship society and a civic legalistic environment. While the colonial and postcolonial civic environments were considered amoral, lacking in values and illegitimate in its interactions with the communal Africanist society, the primordial society was considered moral, trusted and legitimate. For instance, mandatory taxation of adult males by the colonial government was considered a punishment and an 
illegitimate imposition that must be resisted. However, parallel communal structures such as the community development associations with similar mandatory annual contributions were trusted, perceived as moral and considered legitimate. Thus, public officials who appropriated resources from the civic space for communal distribution in the primordial public were treated as accountable and heroes of the community. In effect, Ekeh identifies two conflicting logics: the legal logic (characterizing the civic public) and the communal logic (characterizing the kinship public). In our view, the conflicting logics have created a complex institutional environment in Nigeria, and regulators must navigate the terrain to construct a new culture of accountability using the whistleblowing program.

In conclusion, we observe that the civic government in Ekeh's treatise on corruption is amoral and lacks legitimacy. Meanwhile, a central tenet of institutional theory is the search for and maintenance of legitimacy to attract resources and ensure its sustainability. Drawing on an institutional perspective, we argue that the existence of a dual, contradictory logic, while contributing to institutional complexity may expose challenges and opportunities that could serve as a basis for a template/model for accountability, as anticorruption actors/agents exploit the conflict in logics to reconstruct the institutional environment in favor of low corruption. Thus, Ekeh's two publics treatise can contribute to institutional theory's concept of legitimacy, and both are unified by their emphasis on the social context and societal setting (Goddard et al., 2016). Adoption of Ekeh's insights, together with institutional theory's concepts of legitimacy, institutional work and institutional logics, enabled us to evaluate the emerging nature of whistleblowing as an accountability mechanism in Nigeria (Foegle, 2015). We argue that the crises of legitimacy facing the civic government and its governance institutions cannot be ameliorated by the continuing adoption of the legal/rational model that has failed in eliminating corruption in the postcolonial society. As an accountability mechanism, whistleblowing can contribute to the institutionalization of an anticorruption culture that would increase the legitimacy of the civic government in Nigeria.

\section{Research methodology}

\subsection{Research perspective}

This study adopted a constructivist/interpretivist perspective (Modell et al., 2017) in analyzing embedded corruption in Nigeria. We deployed survey protocol and data from a cross-section of Nigerians to investigate the perceptions of residents on the deployment of whistleblowing as an accountability mechanism to curb corruption and fraud. We conducted purposeful random sampling - a variant of purposive sampling-because we were mainly interested in an in-depth understanding of the challenges and opportunities of whistleblowing as an accountability mechanism in a developing country context, rather than empirical generalization (Patton, 2015) [2]. The survey involved a purposive sampling of the Nigerian urban population, namely: accountants, lawyers, bankers, civil servants and accounting and law students in postsecondary institutions, and respondents were randomly chosen within the purposive sample [3].

\subsection{Data collection}

In 2017, a survey of urban residents in major cities in four geopolitical zones in the country was conducted [4]. In each zone, the survey was administered in a major city, including Lagos and Abuja [5]. In addition to hiring graduates as research assistants for the survey, we were involved in data collection to obtain an "information-rich" purposeful sample. Out of 800 questionnaires administered, a total of 557 respondents completed the survey for this study, indicating a response rate of $70 \%$. While the in-person survey method used significantly contributed to this high response rate, heightened interest among the population about the 
AAAJ 33,6

1344 whistleblowing agenda contributed. Given that the survey was administered in person, most respondents completed their survey instantaneously. Therefore, late response bias was minimal or insignificant. Short sentences and plain language were used in constructing the survey to minimize the difficulty in completion. Additionally, the draft was pretested by eight professionals in Nigeria, and minor changes made based on feedback. Thus, to mitigate social desirability bias, the study used self-completion, purposefully chosen sample, and pilot testing.

\subsection{Survey Deployment and data analysis}

The survey comprises four sections, and the issues raised and questions asked are consistent with prior studies (e.g. Cordis and Lambert, 2017; Luo, 2005). Extant studies have suggested that relevance of instruments and legislations, and/or their acceptability by stakeholders, are important dimensions in analyzing public policy (Morestin, 2012); awareness of whistleblowing law can affect the effectiveness of whistleblowing as an anticorruption measure (Cordis and Lambert, 2017), and understanding how institutions and obstacles work is helpful in devising effective whistleblowing (Nielsen, 2013).

Accordingly, open-ended questions were asked to investigate the perceived level of awareness, relevance and performance of the whistleblowing intervention and the institutional barriers to whistleblowing implementation. Respondents were further probed on the extent they believe the intervention to be successful, in its early stage of implementation, with options as highly successful, promising or unsuccessful. The study relied on the opinions of respondents to assess the level of awareness of the program, among other Nigerians. Demographic information was also gathered on the respondents, including age, gender and job title. Sims and Keenan (1998) have suggested that gender predicts whistleblowing, but age does not have any significant effect. However, their finding is inconsistent with the conclusion in Brennan and Kelly (2007) that older trainee auditors (aged over 25) are less willing to report wrongdoing externally. Taylor and Curtis (2010, p. 31) further document mixed results on the effect of age on whistleblowing likelihood and perseverance. Therefore, this study also examines how citizens perceive the success of whistleblowing as an accountability mechanism, across age and gender.

For obtaining additional data for triangulation, closed-ended questions were included in the survey to further assess perceived relevance, barriers, incentives and determinants of effective whistleblowing, using a five-point Likert scale ranging from "least important" to "most important", with an optional "N/A". This paper generally followed prior studies (e.g. Bakre et al., 2017; Maroun and Atkins, 2014) to construct measures for perceived relevance (i.e. transparency and accountability, improve country's image in the international community, fight against fraud and corruption, enhance public confidence in government and public entities, and recovery oflooted funds) and barriers (i.e. understaffing of regulators, inexperience of regulators in whistleblowing, interference by politicians, risk of poor protection of whistleblowers, and corruption of regulators). Similarly, the study relied on literature (e.g. Latan et al., 2018) and authors' knowledge of the institutional environment to select factors for an incentive to blow the whistle (financial incentive, expose fraud-rationalization, and punish others -victimization) and those that could lead to effective whistleblowing (protection and confidentiality of whistleblowers, expanding whistleblowing offices, expanding whistleblowing law to corporations, educating citizens on whistleblowing, enacting legislations on whistleblowing, and establishing special courts for financial crimes). To confirm that these measures are reliable or internally consistent, they were analyzed using Cronbach's $\alpha$, which showed acceptable values (see Cortina, 1993): perceived relevance (Cronbach's $\alpha=0.92$ ), institutional barriers (Cronbach's $\alpha=0.79$ ), incentives (Cronbach's $\alpha=0.71$ ) and determinants of effective whistleblowing (Cronbach's $\alpha=0.95$ ). However, we adopt with 
caution the measures for "incentives" because the value of its Cronbach's $\alpha(0.71)$ is at the Whistleblowing bottom limit of acceptability (Cortina, 1993; Ursachi et al., 2015).

\section{Findings}

to curb corruption

In this section, we present our findings based on responses to the open-ended and closedended questions, as follows: (1) a demographic profile of respondents; (2) the respondents' perceived relevance and awareness of the whistleblowing, and their opinions on its success; (3) the institutional barriers to effective whistleblowing; (4) a triangulation of findings related to program institutionalization and institutional challenges using the quantitative responses to the closed-ended questions; (5) respondents' perceptions across demographic categories.

\subsection{Demographic profile of respondents}

Table 1 shows the demographic profile of respondents for our independent variables of interest: professional status, age and gender. From the survey sample of 557 Nigerians, 504 respondents $(91 \%)$ indicated their professional status, and 117 of the respondents identified as students $(23 \%)$ while 387 were professionals $(77 \%)$. Of the 422 respondents who disclosed their age, $179(42 \%)$ were adults below 30 years (youths) and $243(58 \%)$ were 30 years and above (older adults). Lastly, 418 respondents indicated their gender, of which 148 (35\%) were female and $276(65 \%)$ were male. Given that we purposefully selected a sample of respondents expected to be knowledgeable about whistleblowing, we do not claim that our sample is representative.

\subsection{Program relevance, awareness and performance}

5.2.1 Program awareness and relevance. A significant majority of respondents (77\%) agree that the level of corruption and fraud in Nigeria makes the whistleblower program relevant and timely, and a cross-section of respondents (66\%) suggest a lack of awareness among the general population of the government's attempts to establish whistleblowing as an accountability mechanism in the country. This, in their view, is a major obstacle in the successful mobilization of the population toward tackling corruption in Nigeria, in comments such as these:

\begin{tabular}{|c|c|c|c|}
\hline & $(N)$ & $(N)$ & \\
\hline Respondents & & 557 & \\
\hline $\begin{array}{l}\text { Occupation* } \\
\text { Students } \\
\text { Professionals } \\
\text { Total }\end{array}$ & $\begin{array}{l}117 \\
387\end{array}$ & 504 & \\
\hline $\begin{array}{l}\text { Age* } \\
\text { Below } 30 \\
30 \text { and above } \\
\text { Total }\end{array}$ & $\begin{array}{l}179 \\
243\end{array}$ & 422 & \\
\hline $\begin{array}{l}\text { Gender* } \\
\text { Female } \\
\text { Male } \\
\text { Total } \\
\text { Note(s): *Not }\end{array}$ & $\begin{array}{l}148 \\
270 \\
\text { c information }\end{array}$ & 418 & $\begin{array}{r}\text { Table 1. } \\
\text { Respondents } \\
\text { demographic profile }\end{array}$ \\
\hline
\end{tabular}


AAAJ 33,6

Most Nigerians are unaware that the program even exists (Respondent \#17).

Nigerians are not really aware of it [whistleblower program] (Respondent \#401).

There is a lack of awareness on the part of the general public (Respondent \#407).

While acknowledging program relevance, a significant number of respondents suggest that the general population is ignorant of the whistleblowing program. In other words, the respondents, while indicating awareness of the program, were of the view that a large section of Nigerians is unaware of the existence, objectives and operations of the whistleblowing program as an accountability mechanism. This is consistent with Ayamba's (2019, p. 7) finding that the whistleblower program suffers from insufficient knowledge of its main legal and operational provisions. A general lack of awareness among the population, in our view, is a harbinger for program paralysis and failure. The lack of whistleblower awareness robs the program of legitimacy (Deephouse et al., 2017) and the absence of grassroots support needed to ensure program success. As suggested by Ayamba (2019, p. 7), regulators need to increase media coverage and exposure of corruption to improve public awareness and engagement with citizens to fight corruption.

Illustrative comments suggest most respondents agree on program relevance $(77 \%)$ :

It is necessary to help stop the abuse of public office and embezzlement of public funds thereby stemming corruption (Respondent \#1).

There seems to be many reasons for the establishment and relevance of the whistleblowing program. They include: to catch those involved in fraudulent activities, to eradicate corruption, to improve the quality or standard of living of ordinary Nigerians (Respondent \#16).

The whistleblowing program helps to fight embezzlement of public funds and bring perpetrators to justice. It also helps to prevent corruption in Nigeria (Respondent \#26).

It is important to help curb crime and corruption in the country and to deter others from having it in mind and engaging in embezzlement (Respondent \#55).

While respondents recognized the relevance of whistleblowing as an accountability mechanism to curb corruption, we argue consistent with Smith $(2007$; 2018) that citizens are caught between the contradiction of participating in corruption for survival and lamenting its adverse effects on their society. In Ekeh's (1975) proposition of the two publics in Africa, the existence of a civic public, with its distrusted and amoral attributes, remains a source of conflict regarding its translation into a kinship public that is trusted and considered moral. From an institutional theory perspective (institutional logics), the dichotomy presented by the dual publics in the Nigerian society is not only a manifestation of a complex institutional environment but remains a difficult and ever-present reality of a sociopolitical creation that is attempting to resolve the obstacles to the development of Nigeria based on cultural and historical antecedents.

5.2.2 Program performance. This paper documents a mixed response to program performance. While some respondents consider the whistleblowing program to be successful because significant progress has been made to hold looters accountable and recover looted funds $(15 \%)$, more respondents maintain that the Nigerian whistleblower program has been unsuccessful in the current effort to stem or eradicate corrupt practices $(22 \%)$. Interestingly, most respondents see the whistleblowing program as promising $(63 \%)$.

From the news, millions of different foreign currencies have been recovered as a result of the whistleblowing policy. So far, I think it has been successful (Respondent \#5).

It is promising because a lot of funds have been recovered and more will be recovered if the government keeps their own part of the bargain (Respondent \#1). 
The reasons advanced for lack of program success include the inability of the government to properly articulate the objectives of the program and its targets, failure to demonstrate accountability via a timely accounting of recoveries, and failure to provide detailed accomplishments with recovered funds. These factors serve to demotivate potential whistleblowers in coming forward with information that could lead to the recovery of looted public funds. Respondents are skeptical about the accounting and accountability mechanisms in place for recovered loot:

Promising, because some of the funds have been recovered, but I'm skeptical because where the money recovered is channeled to is unclear. So, it's like the custodian looting the looted money. But there is hope that things can still change for the better (Respondent \#113).

While I agree with the objectives behind the program, I still think it is unsuccessful because the discovered and recovered funds are misappropriated by those in authority as an adequate account of what the funds were used for is not properly given (Respondent \#4).

They [Government] have not been giving proper account of the funds recovered from whistleblowing thereby making the entire process ineffective (Respondent \#90).

The reference to a proper accounting of recovered funds is interesting given Nigeria's recent experience regarding relooted recoveries. By positioning the whistleblower program as an accountability framework, the EFCC is restrategizing in a way that suggests a desire to engage with citizens in a fundamentally new way of fighting corruption. In combatting corruption in a new way, and by acting as agents of change, EFCC's behavior is consistent with Lawrence and Sudabby's (2006) concept of institutional work. Therefore, we argue that this will involve a combination of building trust in their capacity to demonstrate transparency, ensure and maintain whistleblower confidentiality and safety, and demonstrate its willingness to be accountable for the use of the recovered funds (Alleyne et al., 2013; Reckers-Sauciucand Lowe, 2010).

In conclusion, these respondents' comments indicating program relevance, a general lack of program awareness among the public, and mixed results on program performance, present opportunities for program improvements that can lead to whistleblower program institutionalization. The government should seize the opportunity to adequately mobilize, educate and incentivize citizens about the possibilities that come with minimizing corruption via the whistleblower program. In our view, Nigeria needs a vigilant and informed population to secure the integrity of its treasury, place political actors under surveillance and ensure the proper functioning of the country's fledgling democratic efforts.

\subsection{Institutional barriers to effective whistleblowing}

Respondents are of the view that several institutional obstacles confront government agencies currently responsible for whistleblowing implementation. These barriers include a compromised judiciary, lack of adequately trained staff, poor wages, political interference by politicians they are investigating, structural and organizational limitations that strip the EFCC of constitutional autonomy, and the risk to life and limb in working for these investigative agencies arising from the absence of adequate police protection for agency employees and whistleblowers. The view pertaining to poor wages is consistent with the suggestions by Agbiboa (2012) that civil servants in Nigeria receive paltry wages. Respondents' comments include:

Legislative infrastructure is required. Get a neutral and unbiased whistleblowing legal framework to be passed by the NASS [6]. The director could only be appointed by the body of Benchers and not by the executive, but it can nonetheless be sanctioned by the senate (Respondent 78).

Lack of training, suitably qualified personnel, and poor/insufficient wages (Respondent \#54). 
AAAJ 33,6

The protection and compensation of whistleblowers is perceived by respondents $(87 \%)$ as the greatest challenge to the effective use of whistleblowing as an accountability mechanism. According to a respondent:

The whistleblowers are playing a major role in the government's anti-corruption drive. But exposing corruption can be at great cost in Nigeria, a country where corruption is deeply entrenched, and impunity has been the norm. Whistleblowers, like journalists and anti-corruption activists, face threats including the risk of assassination (Respondent \#513).

One of the key determinants of whistleblowing is the risk associated with the safety of the whistleblower (Alleyne et al., 2013; Reckers-Sauciucand Lowe, 2010). In Nigeria, where assassinations are common (Falana, 2018; Ayamba, 2019), the high risk faced by both whistleblowers and EFCC's operatives is real. Foegle (2015) suggests that whistleblower safety should be considered a human right to further entrench its relevance and criticality in the fight against corruption. The success of the whistleblowing program as an accountability mechanism would include the implementation of formal processes to ensure whistleblower safety and protection for employees of the EFCC.

Respondents also allude to the clear and present danger of investigating powerful political/government actors who act with impunity and ruthlessness against any perceived opponent or threat to their glamorous and/or prodigal lifestyle.

The judiciary and the politicians are the biggest obstacles of this program. Because the judiciary needs to back-up the program but most of the judiciary are corrupt and this program is at a disadvantage (Respondent \#491).

The politician[s] who are the corrupt and the executors of the scheme will not support it, the institution implementing it is not known as well, the awareness is still low and the publicity still low, the institutions implementing it should be transparent and open (Respondent \#434).

The obstacles to whistleblowing in Nigeria include resistance by some political elites, corrupt leaders and politicians, lack of independence, little or no protection of the whistleblower (Respondent \#406).

In effect, most respondents $(72 \%)$ negatively view politicians (the target investigative constituency) whose interests are at stake as a major operational obstacle toward a successful implementation of the program. Ayamba (2019, p. 7) insists that the fear of victimization from political office holders is real and ever present as politicians in Nigeria have "an aura of invincibility around them". Our study finds that in addition to parochial interests and lack of commitment to national/patriotic values, some Nigerians perceive the whistleblower program as a political witch-hunt that targets certain geopolitical zones of the country and opposition politicians in its current operational focus. Thus, navigating the multiple barriers posed by Nigeria's complex institutional environment in a pluralistic and deeply divided country is critical to the whistleblowing program's success.

\subsection{Program institutionalization and institutional environment - a triangulation}

Quantitative data were analyzed in order to triangulate the findings with the qualitative data obtained from the open-ended questions. Using the 557 questionnaires, this paper analyzed the degree of importance that respondents attach to whistleblowing purposes (program relevance), perceived success (program performance), obstacles to whistleblowing as an effective accountability mechanism (institutional barriers), incentives and determinants, and variations across groups. Following Callahan and Collins (1992), our paper presents observed frequencies and the associated mean. The calculations exclude no responses [7]. Although, both frequency and mean are presented, this paper finds the frequency measure more useful for analysis and interpretation. The 5-point Likert scale has been collapsed so that 1 and 2 are 
"slightly important", 3 is "fairly important", 4 is “important", 5 is "very important", while "N/ A" is "not important at all".

5.4.1 Relevance, barriers, incentives and determinants. Table 2 below shows the perceived importance of the purposes for establishing whistleblowing or program relevance. Approximately $69 \%$ of the respondents perceive fighting fraud and corruption as important or very important, and $79 \%$ of those respondents rank corruption and fraud as a very important purpose that the whistleblowing program must address. $61 \%$ of respondents identify recovering funds, along with transparency and accountability, as either important or very important. Improving the country's image in the international community garners the least attention, with only half of respondents describing it as important or very important. Table 2 also presents other interesting findings. While $17 \%$ of respondents see recovering stolen funds along with transparency and accountability as unimportant, $14 \%$ perceive fighting fraud as unimportant [8]. These results suggest that many professional elites in Nigeria do not see the need to fight corruption. This finding further supports the arguments that the logic of corruption is largely accepted in Nigeria (Agbiboa, 2012; Bakre and Lauwo, 2016). Moreover, as it is widely held that elites are responsible for the vast majority of stolen wealth in the country (Ijewereme, 2015), some of the respondents may be complicit in corruption.

Table 3 presents respondents' perception of the importance of various institutional obstacles identified in prior studies (e.g. Nielsen, 2013) and from a knowledge of the institutional environment. Less than a quarter of the respondents perceive understaffing as important. One striking finding in this table is that approximately $35 \%$ of the respondents describe the understaffing of EFCC and the Ministry of Finance as not important at all. The majority of respondents $(56 \%)$ view politicians and riskiness of whistleblowing as major institutional obstacles that undermine effective whistleblowing. Interestingly, respondents

\begin{tabular}{|c|c|c|c|c|c|c|c|}
\hline & \multirow[b]{2}{*}{$\begin{array}{c}\text { Not } \\
\text { important }\end{array}$} & \multicolumn{3}{|c|}{ Observed frequency $(f)$} & \multirow[b]{2}{*}{$\begin{array}{c}\text { Very } \\
\text { important }\end{array}$} & \multirow{2}{*}{$\begin{array}{c}\text { Mean } \\
(\bar{x}) \\
\end{array}$} & \\
\hline & & $\begin{array}{l}\text { Slightly } \\
\text { important }\end{array}$ & $\begin{array}{c}\text { Fairly } \\
\text { important }\end{array}$ & Important & & & \\
\hline Improve image & 88 & 116 & 73 & 73 & 202 & 3.0 & \\
\hline $\begin{array}{l}\text { Fight fraud and } \\
\text { corruption }\end{array}$ & 77 & 59 & 36 & 79 & 301 & 3.6 & \\
\hline Enhance confidence & 100 & 71 & 85 & 87 & 209 & 3.2 & \\
\hline $\begin{array}{l}\text { Transparency and } \\
\text { Accountability }\end{array}$ & 96 & 67 & 50 & 92 & 247 & 3.4 & $\begin{array}{r}\text { Table } 2 . \\
\text { Perceived relevance of }\end{array}$ \\
\hline Recover funds & 94 & 73 & 50 & 70 & 265 & 3.4 & whistleblowing \\
\hline
\end{tabular}

\begin{tabular}{|c|c|c|c|c|c|c|c|}
\hline & \multicolumn{5}{|c|}{ Observed frequency $(f)$} & \multicolumn{2}{|l|}{ Mean } \\
\hline & $\begin{array}{c}\text { Not } \\
\text { important }\end{array}$ & $\begin{array}{l}\text { Slightly } \\
\text { important }\end{array}$ & $\begin{array}{l}\text { Fairly } \\
\text { important }\end{array}$ & Important & $\begin{array}{c}\text { Very } \\
\text { important }\end{array}$ & & \\
\hline Ministry understaffed & 199 & 162 & 75 & 47 & 69 & 1.8 & \\
\hline EFCC understaffed & 194 & 146 & 78 & 60 & 72 & 2.0 & \\
\hline Inexperienced regulators & 172 & 99 & 93 & 70 & 118 & 2.4 & \\
\hline $\begin{array}{l}\text { Politicians undermine } \\
\text { whistleblowing }\end{array}$ & 111 & 76 & 51 & 65 & 248 & 3.2 & \\
\hline $\begin{array}{l}\text { Whistleblowing is too } \\
\text { risky }\end{array}$ & 105 & 78 & 61 & 70 & 238 & 3.2 & $\begin{array}{r}\text { Perceived importance } \\
\text { of institutional }\end{array}$ \\
\hline $\begin{array}{l}\text { EFCC and others will } \\
\text { become corrupt }\end{array}$ & 152 & 116 & 77 & 62 & 145 & 2.5 & $\begin{array}{l}\text { obstacles to effective } \\
\text { whistleblowing }\end{array}$ \\
\hline
\end{tabular}


AAAJ 33,6

\section{0}

Table 4.

Perceived importance of various incentives are also concerned that EFCC may become corrupt, and 38\% rate this factor as an important institutional obstacle to the use of whistleblowing as an accountability mechanism. Thus, the quantitative data further provides complementary evidence to the qualitative data that politicians and risks to whistleblowers are the major obstacles to the deployment of whistleblowing as an accountability mechanism in Nigeria. Our survey results further suggest that the Nigerian institutional context is different from a developed country context, such as the USA, in terms of understaffing and experience of the regulators (see Nielsen, 2013). A possible explanation is that the EFCC, as the anticorruption institution with the highest ranking in the effectiveness in Nigeria (United Nations Office on Drugs and Crime, 2017), may have an edge in recruiting and retaining employees in the country.

A summary of respondents' beliefs on what would motivate citizens to engage in the whistleblowing program is presented in Table 4. Respondents suggest that citizens would engage in whistleblowing to receive financial rewards and expose the fraud. For example, $46 \%$ of the respondents strongly believe that citizens will blow the whistle for financial rewards (i.e. very important), and $41 \%$ of the respondents share similar strong beliefs that inherent desire to expose fraud (rationalization) would incentivize citizens to whistle-blow. Fewer respondents believe that citizens would blow the whistle just to punish others (victimization). Our findings are generally consistent with the empirical evidence in Latan et al. (2018) that financial incentives and rationalization affect whistleblowing intentions in Indonesia.

Table 5 shows the findings on what respondents believe should lead to effective whistleblowing. It shows strong supports for all listed determinants, but respondents discriminate on the relative importance of these determinants. For instance, $70 \%$ state that the protection of whistleblowers is important or very important. Along the same line (i.e. important or very important), $64 \%$ favor educating Nigerians on whistleblowing; $62 \%$ suggest enacting laws; $60 \%$ recommend special courts; $59 \%$ support expanding the program to all zones; $58 \%$ pick financial incentives; and $54 \%$ feel that the program should be copied by

\begin{tabular}{|c|c|c|c|c|c|c|}
\hline & \multicolumn{5}{|c|}{ Observed frequency $(f)$} & \multirow{2}{*}{$\begin{array}{r}\text { Mean } \\
(\overline{\mathrm{x}})\end{array}$} \\
\hline & $\begin{array}{c}\text { Not } \\
\text { important }\end{array}$ & $\begin{array}{c}\text { Slightly } \\
\text { important }\end{array}$ & $\begin{array}{c}\text { Fairly } \\
\text { important }\end{array}$ & Important & $\begin{array}{c}\text { Very } \\
\text { important }\end{array}$ & \\
\hline $\begin{array}{l}\text { Financial } \\
\text { reward }\end{array}$ & 103 & 96 & 51 & 72 & 230 & 3.1 \\
\hline Punish others & 118 & 125 & 64 & 68 & 177 & 2.8 \\
\hline Expose fraud & 102 & 84 & 71 & 70 & 225 & 3.1 \\
\hline
\end{tabular}

\begin{tabular}{|c|c|c|c|c|c|c|}
\hline & \multicolumn{5}{|c|}{ Observed frequency $(f)$} & \multirow{2}{*}{$\begin{array}{l}\text { Mean } \\
(\bar{x})\end{array}$} \\
\hline & $\begin{array}{c}\text { Not } \\
\text { important }\end{array}$ & $\begin{array}{l}\text { Slightly } \\
\text { important }\end{array}$ & $\begin{array}{l}\text { Fairly } \\
\text { important }\end{array}$ & Important & $\begin{array}{c}\text { Very } \\
\text { important }\end{array}$ & \\
\hline Financial incentives & 104 & 72 & 58 & 73 & 245 & 3.2 \\
\hline $\begin{array}{l}\text { Protection/ } \\
\text { confidentiality }\end{array}$ & 89 & 56 & 37 & 41 & 329 & 3.6 \\
\hline Expansion to zones & 114 & 57 & 53 & 73 & 255 & 3.3 \\
\hline $\begin{array}{l}\text { Expansion to private } \\
\text { sector }\end{array}$ & 116 & 77 & 63 & 63 & 233 & 3.1 \\
\hline Educating Nigerians & 103 & 53 & 40 & 59 & 296 & 3.5 \\
\hline Enacting laws & 115 & 51 & 46 & 74 & 266 & 3.3 \\
\hline Special courts & 137 & 48 & 34 & 54 & 279 & 3.2 \\
\hline
\end{tabular}

Table 5.

Perceived importance of determinants of effective whistleblowing 
corporations. Thus, the need to protect whistleblowers received the highest ranking, followed Whistleblowing by education and legislation [9].

These findings show that respondents' answers to the closed-ended questions relating to program institutionalization and institutional environments are generally identical to their responses to the open-ended questions.

5.5 Perceptions across demographic categories to curb corruption and fraud

First, we split the professionals who are expected to be more knowledgeable about the whistleblowing from students [10]. We then analyze perceived purpose, barriers, incentives, determinants and success, using a nonparametric test (Mann-Whitney $U$ test) to compare the mean values of the two groups. Table 6 below shows that students have significantly higher mean values than the professionals, in almost all measures of whistleblowing purpose, barrier, incentive and determinant, and are more skeptical of its success. Thus, in comparison with the professionals, the students more strongly identify with the purposes, barriers, incentives and determinants of whistleblowing on one hand; but on the other hand, they have stronger reservations than the professionals on how successful the whistleblowing has been in Nigeria. Given the significant differences noted above, we performed an additional analysis based on responses from the professionals only, and the result from this subsample is consistent with the result from the full sample. Therefore, we do not report these [11].

Second, we use cross-tabulation analysis to examine whether respondents' overall perceived success of the whistleblowing intervention is associated with age and gender. Due to missing information on performance and age, we retained a sample size of 422 for this analysis. We analyze perceived success (highly successful, promising and unsuccessful) across age (youths below the age of 30 years and older individuals above 30 years) and gender. As Table 7 indicates, the youths generally differ from older adults in their perception. Of the youths surveyed, respondents who perceive the program as unsuccessful $(26 \%)$ are roughly twice those who perceive it as highly successful $(12 \%)$. Older adults have a more favorable opinion on the success of the whistleblowing program, as approximately $18 \%$ describe it as both very successful and as unsuccessful. An overwhelming majority across the two groups indicate that the program is promising - $62 \%$ for youth and 63 for older adults. Overall, $15 \%, 63$ and $22 \%$ of all respondents perceive the whistleblowing program as highly successful, promising and unsuccessful, respectively. As the Pearson Chi-Squared test is significant at a $10 \%$ confidence level, the young and the older generations differ in their assessments of the whistleblowing program. However, Phi and Cramer's V shows that the strength of association is low. In conclusion, the respondents are skeptical about admitting that the program is highly successful or unsuccessful, but they generally believe that the whistleblowing program offers good prospects, as an accountability mechanism, for curbing corruption and fraud.

Last, we cross-tabulated perceived success and gender but find an insignificant association. Our cross-tabulation results are not reported for parsimony and readability [12]. We conclude that while the perception of whistleblowing success by residents is associated with age, such a perception is not significantly associated with gender, based on survey evidence from Nigeria.

\section{Discussion and conclusion}

\subsection{Discussion}

The findings in this paper point to the need for a strategic program of culture-based institutional reform to combat corruption in Nigeria (Bamidele et al., 2016; Luo, 2005). The findings suggest that steps must be taken within the accepted norms and traditions of the 
AAAJ

33,6

\section{2}

Table 6.

Nonparametric test for differences in perceptions between students (S) and professionals $(\mathrm{P})$

\begin{tabular}{|c|c|c|c|c|c|}
\hline & & & & $\begin{array}{l}\text { Whitney } \\
\text { aparison }\end{array}$ & \\
\hline & & Group & $\begin{array}{c}\text { Mean } \\
\text { rank }\end{array}$ & $Z$ score & $p$ \\
\hline Purposes & Improve image & $\begin{array}{l}S \\
P\end{array}$ & $\begin{array}{l}277.99 \\
244.79\end{array}$ & -2.246 & 0.025 \\
\hline & Fight fraud and corruption & S & 282.16 & -2.843 & 0.004 \\
\hline & Enhance confidence & $\begin{array}{l}\mathrm{r} \\
\mathrm{S} \\
\mathrm{P}\end{array}$ & $\begin{array}{l}243.53 \\
270.27 \\
247.13\end{array}$ & -1.573 & 0.116 \\
\hline & Transparency and Accountability & $\begin{array}{l}\mathrm{S} \\
\mathrm{P}\end{array}$ & 282.51 & -2.719 & 0.007 \\
\hline & Recover funds & $\begin{array}{l}\mathrm{S} \\
\mathrm{P}\end{array}$ & $\begin{array}{l}287.64 \\
241.88\end{array}$ & -3.229 & 0.001 \\
\hline Barriers & Ministry understaffed & $\begin{array}{l}\mathrm{S} \\
\mathrm{P}\end{array}$ & $\begin{array}{l}273.55 \\
246.14\end{array}$ & -1.824 & 0.068 \\
\hline & EFCC understaffed & $\mathrm{S}$ & $\begin{array}{l}278.94 \\
24383\end{array}$ & -2.335 & 0.020 \\
\hline & Inexperienced regulators & $\begin{array}{l}\mathrm{S} \\
\mathrm{P}\end{array}$ & $\begin{array}{l}278.98 \\
244.49\end{array}$ & -2.289 & 0.022 \\
\hline & Politicians undermine whistleblowing & $\begin{array}{l}\mathrm{S} \\
\mathrm{P}\end{array}$ & $\begin{array}{l}276.65 \\
244.53\end{array}$ & -2.241 & 0.025 \\
\hline & Whistleblowing is too risky & $\begin{array}{l}\mathrm{S} \\
\mathrm{P}\end{array}$ & $\begin{array}{l}255.68 \\
251.54\end{array}$ & -0.286 & 0.775 \\
\hline & EFCC and others will become corrupt & $\begin{array}{l}\mathrm{S} \\
\mathrm{P}\end{array}$ & $\begin{array}{l}287.05 \\
242.05\end{array}$ & -2.992 & 0.003 \\
\hline Incentives & Financial reward & $\begin{array}{l}\mathrm{S} \\
\mathrm{P}\end{array}$ & $\begin{array}{l}296.68 \\
239.14\end{array}$ & -3.956 & 0.000 \\
\hline & Punish others & $\begin{array}{l}\mathrm{S} \\
\mathrm{P}\end{array}$ & $\begin{array}{l}248.72 \\
253.64\end{array}$ & -0.330 & 0.742 \\
\hline & Expose fraud & $\begin{array}{l}\mathrm{S} \\
\mathrm{P}\end{array}$ & $\begin{array}{l}273.62 \\
246.12\end{array}$ & -1.884 & 0.060 \\
\hline Determinants & Financial incentives & $\begin{array}{l}\mathrm{S} \\
\mathrm{P}\end{array}$ & $\begin{array}{l}281.45 \\
24375\end{array}$ & -2.618 & 0.009 \\
\hline & Protection/ confidentiality & $\begin{array}{l}\mathrm{S} \\
\mathrm{P}\end{array}$ & $\begin{array}{l}279.50 \\
244.34\end{array}$ & -2.701 & 0.007 \\
\hline & Expansion to zones & $\begin{array}{l}\mathrm{S} \\
\mathrm{P}\end{array}$ & $\begin{array}{l}282.03 \\
243.57\end{array}$ & -2.695 & 0.007 \\
\hline & Expansion to private sector & $\begin{array}{l}\mathrm{S} \\
\mathrm{P}\end{array}$ & $\begin{array}{l}281.09 \\
24386\end{array}$ & -2.565 & 0.010 \\
\hline & Educating Nigerians & $\begin{array}{l}\mathrm{S} \\
\mathrm{P}\end{array}$ & $\begin{array}{l}278.89 \\
244.52\end{array}$ & -2.514 & 0.012 \\
\hline & Enacting laws & $\begin{array}{l}\mathrm{S} \\
\mathrm{P}\end{array}$ & $\begin{array}{l}282.05 \\
24357\end{array}$ & -2.725 & 0.006 \\
\hline & Special courts & $\begin{array}{l}\mathrm{S} \\
\mathrm{P}\end{array}$ & $\begin{array}{l}275.20 \\
24564\end{array}$ & -2.120 & 0.034 \\
\hline Success* & $\begin{array}{l}\text { Success of whistleblowing as an accountability } \\
\text { mechanism }\end{array}$ & $\begin{array}{l}\mathrm{S} \\
\mathrm{P}\end{array}$ & $\begin{array}{l}232.64 \\
258.50\end{array}$ & -1.852 & 0.064 \\
\hline
\end{tabular}

Note(s): *Coded Success (Unsuccessful, Promising and Highly successful) as Ordinal

institutional environment, to gain a new legitimacy in the deployment of whistleblowing as an accountability mechanism, and move the country away from the previous ways of doing things to a new low corruption environment anchored on shared and accepted indigenous cultural practices and context. Put differently, the society must be proactively sensitized to the concept of a "new normal" anchored in strong, efficient and enduring institutions. The 


\begin{tabular}{|c|c|c|c|c|c|c|c|}
\hline & & & & eived succes: & & & Thistleblowing \\
\hline & & & successful & Promising & Unsuccessful & Total & corruptior \\
\hline Age & Older & Count & 33 & 113 & 33 & 179 & and trau \\
\hline & Adults & Expected Count & 26.7 & 112 & 40.3 & 179 & \\
\hline & & $\%$ within Age & $18.4 \%$ & $63.1 \%$ & $18.4 \%$ & $100 \%$ & \\
\hline & & $\begin{array}{l}\% \text { within Perceived } \\
\text { Success }\end{array}$ & $52.4 \%$ & $42.8 \%$ & $34.7 \%$ & $42.4 \%$ & 135 \\
\hline & & $\%$ of Total & $7.8 \%$ & $26.8 \%$ & $7.8 \%$ & $42.4 \%$ & \\
\hline & Youths & Count & 30 & 151 & 62 & 243 & \\
\hline & & Expected Count & 36.3 & 152 & 54.7 & 243 & \\
\hline & & $\%$ within Age & $12.3 \%$ & $62.1 \%$ & $25.5 \%$ & $100 \%$ & \\
\hline & & $\%$ within Perceived & $47.6 \%$ & $57.2 \%$ & $65.3 \%$ & $57.6 \%$ & \\
\hline & & Success & & & & & \\
\hline Total & & Count & $\begin{array}{l}7.1 \% \\
63\end{array}$ & $\begin{array}{c}50.8 \% \\
264\end{array}$ & $\begin{array}{c}14.1 \% \\
95\end{array}$ & $\begin{array}{c}51.0 \% \\
422\end{array}$ & \\
\hline & & Expected Count & 63 & 264 & 95 & 422 & \\
\hline & & $\%$ within Age & $14.9 \%$ & $62.6 \%$ & $22.5 \%$ & $100 \%$ & \\
\hline & & $\%$ within Perceived & $100 \%$ & $100 \%$ & $100 \%$ & $100 \%$ & \\
\hline & & $\begin{array}{l}\text { Success } \\
\% \text { of Total }\end{array}$ & $14.9 \%$ & $62.6 \%$ & $22.5 \%$ & $100 \%$ & \\
\hline Note & (s): Pears & i-Squared $\left(X^{2}\right)$ : 4.891* & & & $\angle 2.5 \%$ & $100 \%$ & $\begin{array}{r}\text { Table } 7 . \\
\text { Cross-tabulation of }\end{array}$ \\
\hline$*$ Sign & ficant $(2-$ & at 0.1 level & & & & & perceived success \\
\hline 0 cells & $(0.0 \%) \mathrm{h}$ & xpected count less than & nimum expe & count is 26.7 & & & \\
\hline
\end{tabular}

new normal must build on a collective abhorrence of corruption and an embrace of a liberating and better future. What is argued here is that any accountability mechanism has a limited range and reach where a culture of public ethics is not widely accepted and supported, consistent with Ekeh's conception of a preexisting moral and legitimate cultural anchors.

According to North (1990, p. 3), "Institutions are the rules of the game in a society or, more formally, are the humanly devised constraints that shape human interaction". Institutions, especially the culturally relevant and politically acceptable institutions, represent the foundations of social and economic interactions, and because they project legitimating behaviors and attributes, they represent accepted standards of action and behaviors (Deephouse et al., 2017; DiMaggio and Powell, 1983; Dacin et al., 2002). While political institutions are centers of legitimacy and accepted practices and behaviors, economic and socio-cultural institutions are equally important in mitigating corruption (Scott, 2014; Deephouse et al., 2017). According to Granovetter (1992), economic institutions are socially constructed, and therefore subject to underlying social conditions. Denedo et al. (2017) find that counter-accountability worked as part of campaign measures to address power imbalance, reform government institutions and change corporate practices in Nigeria. This paper adds that similar sets of accountability mechanisms that empower citizens to take ownership of the corruption war are needed. In our view, whistleblowing as an accountability framework fits this narrative.

The increased transparency and accountability that come with a whistleblower program have led us to examine the role that accounting can play in the fight against corruption and fraud in Nigeria. Accounting has been involved in the long and ongoing fight against corruption (Everett et al., 2007). Major institutions such as the United Nations, OECD and Transparency International are already engaged in the fight, and accounting complements their efforts. For instance, the audit process has been mobilized via the heads of the supreme audit institutions (SAIs) in developing countries to train and retrain auditors in this regard. 
AAAJ 33,6

1354

Everett et al. (2007, p. 520) suggest that accounting technologies could be deployed in three key areas. First, as a control technology or set of strategies that target improvements in major institutional structures of the state, including "legal, electoral, educational, and other institutional systems". Second, accounting could be mobilized as an exit strategy from a corrupt situation. An exit strategy assumes alternative platforms exist to a corrupt situation, and thus, favors state pull back from excessive participation in activities that enable corruption. Accounting technologies, using the instrumentality of financial and management accounting tools, are best positioned to deploy in a competitive situation to draw attention to the bottom-line performance as a measure of efficiency (Iyoha and Oyerinde, 2010). However, our study finds limited alternative platforms for exit in Nigeria. For illustration, private sector employment opportunities are scanty as the Nigerian economy is driven by the public sector (Agbiboa (2012), the Nigerian government's pledge to expand the private sector has been slow, and the country's economic freedom is below the world average (The Heritage Foundation, 2019). Third, according to Everett et al., accounting performs a "voice" role. Here accounting could give voice to the real victims of corruption and enable their experiences to become a stronger tool to fight corruption through an accounting of their lived experiences and educating the public through the legitimating use of established accounting technologies. Along with this narrative, Rahaman (2009) finds that financial auditing increasingly plays a major role in fighting fraud and financial mismanagement in the government sector in Ghana.

These suggestions have significant implications for the roles that accounting ought to play in the deployment of whistleblowing as an accountability mechanism in a developing country. Accounting would be useful in setting standards for evaluating whistleblowing programs, gathering evidence and comparing actual results with set standards. Accounting can help to determine how the program will be evaluated, including instituting a process evaluation, an impact assessment and an outcome evaluation. Indeed, policymakers must engage experienced professional accountants not only to investigate or regulate but also to devise objective criteria for evaluating and improving whistleblowing programs. However, accounting may also be used to manipulate a process to the benefit of politicians and other interest groups (Bakre et al., 2017).

\subsection{Conclusion}

From an institutional theory perspective, this study has drawn evidence from Nigeria to examine the challenges and opportunities for deployment of whistleblowing as an effective accountability mechanism in a developing democracy. While the limited time-window may present an incomplete picture of the challenges and opportunities in Nigeria, the obstacles posed by the political class coupled with various institutional obstacles impede accountability frameworks that could advance the fight against corruption. However, if the government can institutionalize an anticorruption culture using whistleblowing intervention, there are prospects that whistleblowing as an accountability mechanism may become successful in curbing corruption and fraud in the country. Corruption and fraud are complex, multidimensional and secretive activities that present unique challenges to accountable institutions (Carson and Prado, 2016).

Based on the results of this study, Nigeria's whistleblowing program needs substantial and urgent reform. First, a significant part of the respondents perceives whistleblowing as highly relevant to curbing corruption and fraud but decries a strikingly low level of whistleblowing program awareness among the citizenry. Given that effectiveness of whistleblowing law depends on the level of awareness of the law (Cordis and Lambert, 2017), mass mobilization for a grass-root information campaign needs to address the relative obscurity of this intervention. Regulators may use posters, billboards, television adverts, radio commercials, seminars, and social media to sensitize the population. An awareness campaign strategy designed to engage stakeholders could build on trusted cultural 
structures such as the community cultural associations, traditional institutions and religious bodies that have historical and cultural acceptance in Nigeria (Akinkugbe, 2018). According to Bamidele et al. (2016), even though there have been instances where culture is invoked to support corruption, indigenous Africanist societies abhor corruption, and this corruptionabhorrence culture must be invoked to defeat corruption in Africa's postcolonial society.

Second, tackling corruption will require more than a single agency approach and must be anchored on a reformed set of core institutions, including political, legislative, judicial, sociocultural and private sector/civil service institutions imbued with new logics and values (Gabbioneta et al., 2013). For example, the Office of the Auditor General of the Federation(OAGF) must be independent and adequately funded to perform its role of enforcing accountability and transparency in the public sector. Although the supreme audit institution plays a critical role in curbing corruption (Dye and Stapenhurst, 1998), the OAGF has been underfunded in Nigeria (Inyang, 2016). Appropriation to the OAGF relative to total national appropriation decreased by roughly $68 \%$ between 2014 and 2019 in the country [13]. Importantly, regulatory institutions must establish credibility and independence to enhance legitimacy (Scott, 2014; Deephouse et al., 2017). Our study suggests that politicians are a major institutional obstacle to whistleblowing effectiveness because of the perception that they undermine whistleblowing efforts, and discredit whistleblowers and regulators. Thus, strong legislative and judicial mandates, supported by enabling political and socio-cultural institutions, would ensure the protection of the anticorruption infrastructure, and insulate it from political interference, with reporting responsibility directly to parliament. We propose that to strengthen Nigeria's institutional environment requires a committed presidency with a positive tone at the top, and a strong deterrence signal to corrupt politicians and corporate leaders by subjecting them to prosecution and stringent jail term, naming and shaming, and through transparent utilization of recovered funds for economic development. An enabling anticorruption institutional environment also demands a social-cultural shift from deeprooted tribalistic and nepotistic norms, values and beliefs to cultural values and norms supportive of national unity and equity, transparency and fairness. Additionally, for Nigeria to effectively deploy whistleblowing as an accountability mechanism, there must be an active media and NGOs untethered to function as watchdogs, gatekeepers and scorekeepers. An independent media and credible NGO sector can play an active role in orchestrating a new social environment that emphasizes basic values such as paying a living wage to public servants and on time (Agbiboa, 2012) and holding corrupt officials accountable. Further, a viable fiscal and monetary policy is needed to support private enterprises and economic growth such that citizens can find employment in the private sector. We argue that if credible NGOs and independent media can more actively engage in the war on corruption, and the private sector can provide a robust alternative to public sector employment that results in less economic reliance on the state, then a socio-cultural shift to new logics and values based on accountability and equity could emerge in Nigeria.

With the means to fast-track corruption cases and demonstrate timely and effective judicial action and dispensation of justice, a dedicated anticorruption judicial arrangement is needed. It is the legalistic mechanism used by organizations, not legal procedures (Alleyne et al., 2013), and the fairness of whistleblowing procedures and outcomes (Seifert et al., 2010) that encourage whistleblowing. In our view, the institutionalization of effective whistleblowing as a viable accountability mechanism would not only inhibit the ability of corrupt politicians to extract extortive rents from the public purse it would curtail the ability of corporate executives to divert corporate assets to private use. We argue that until Nigeria citizens can curtail the excesses of their political leaders and corporate executives, via interventions that hold those leaders accountable, reducing corruption and fraud in Nigeria will remain a fantasy. Even with endemic corruption in Nigeria, very few people have gone to jail, underscoring the limits of the current system. 
AAAJ 33,6

1356

Third, operationally, and related to the above point, regulatory institutions must be adequately resourced (Nielsen, 2013) and granted fiscal autonomy to operate as designed, without undue financial constraints. Effectively, the anticorruption agency responsible for whistleblowing (EFCC) needs operational transformation and protection via a constitutional provision that signals a commitment to strategically (re)position it and institutionalize the anticorruption fight for the long-term. We argue that, besides a weak institutional environment, a major problem in Nigeria's fight against corruption and fraud lies in the failure to institutionalize interventions such as whistleblowing as an effective accountability mechanism. Nigeria has had many anticorruption measures, but none became institutionalized (Ijewereme, 2015; Ogungbamila, 2014).

Fourth, given the real dangers of victimization, antiretaliation measures must be adopted (Farag and Dworkin, 2016) and whistleblowers and witnesses adequately protected; otherwise, the whistleblowing intervention would quickly become another unsuccessful effort. Our study finds that serious threats to whistleblowers and witnesses, especially the risk of physical harm or being killed (Ayamba, 2019; Falana, 2018), complicate the institutional terrain that regulators in Nigeria must navigate for effective whistleblowing. The Ministry of Finance states on its website the recovery of 11,625 million naira, approximately US $\$ 32$ million, and the receipt of "2,150 communications and 337 tips" since the program was introduced in 2016 (Federal Ministry of Finance, 2017).These recoveries, coupled with a traditional culture that abhors corruption, suggest there is a culture for whistleblowing in Nigeria. This is a positive development for the deployment of whistleblowing as an accountability mechanism, and for the fight against corruption in the country. For example, corruption in the criminal justice sector has decreased in Nigeria. Between 2016 and 2019, bribes to police officers, judges/ magistrates and prosecutors decreased by $13 \%, 11 \%$ and $10 \%$ respectively (United Nations Office on Drugs and Crime, 2019). Our study also shows that citizens are optimistic about the whistleblowing program, and this optimism persists across gender and age.

According to Greenwood et al. (2011, p. 318), "Organizations face institutional complexity whenever they confront incompatible prescriptions from multiple institutional logics". Therefore, to tackle a complex phenomenon in a multiethnic society where corruption has been widespread for decades requires a multiplicity of institutional reform efforts. One adoptable and adaptable approach would be to model Brazil's multiple layers of anticorruption program (Carson and Prado, 2016). Adopting an institutional multiplicity strategy in addressing corruption, Brazil employed several agencies and authorities at the same time in tackling corruption. This multilayered, multiorganizational approach has proved successful (Carson and Prado, 2016). While the whistleblowing intervention is a good start, it is inadequate, in its current form, to tackle decades of entrenched corruption in Nigeria. Regulators need to institutionalize a culture of accountability and transparency, through a comprehensive whistleblowing program, that permeates all strata of the economy, including the private/for-profit and nonprofit sectors. Given the existence of both civic and kinship logics in Nigeria (Ekeh, 1975) and conflicting institutional logics, we recommend that the EFCC should consider the unique challenges and opportunities in the Nigerian institutional environment and build new logics to maintain legitimacy. Furthermore, the EFCC may consider adapting its human agency role to create a new institutional environment conducive to low corruption. This is consistent with what Lawrence and Suddaby (2006), and Lawrence et al. (2009) consider as constituting institutional work - where actors are motivated to take action that creates, maintains or destroys an existing institution that aligns with their interests. Consistent with Misangyi et al.'s (2008), our study suggests that leveraging existing institutional logics and reconstructing institutional environment are vital components necessary to defeat corruption in Nigeria. Drawing on our research findings, we have used an institutional perspective to present the challenges and opportunities for deployment of whistleblowing as an effective accountability mechanism in Nigeria in Table 8 below. 


\begin{tabular}{|c|c|c|c|c|c|}
\hline \multirow{2}{*}{\multicolumn{2}{|c|}{$\begin{array}{l}\text { Institutional environment } \\
\text { Challenges }\end{array}$}} & \multirow[b]{3}{*}{$\begin{array}{l}\text { Opportunities } \\
\text { Committed } \\
\text { presidency; positive } \\
\text { tone at the top; } \\
\text { recovery of looted } \\
\text { funds*; prosecution } \\
\text { and jail term*; naming } \\
\text { and shaming* }\end{array}$} & \multicolumn{2}{|c|}{ Program institutionalization } & \multirow{3}{*}{$\begin{array}{r}\text { Whistleblowing } \\
\text { to curb } \\
\text { corruption } \\
\text { and fraud } \\
\mathbf{1 3 5 7} \\
\end{array}$} \\
\hline & & & Challenges & Opportunities & \\
\hline $\begin{array}{l}\text { Political } \\
\text { environment / } \\
\text { Executive }\end{array}$ & $\begin{array}{l}\text { Corrupt powerful } \\
\text { politicians, } \\
\text { corrupt police }\end{array}$ & & Lack of awareness & $\begin{array}{l}\text { Posters; billboards; } \\
\text { television adverts; } \\
\text { radio commercials; } \\
\text { seminars; social } \\
\text { media; newspapers/ } \\
\text { independent media }\end{array}$ & \\
\hline $\begin{array}{l}\text { Legislative } \\
\text { environment }\end{array}$ & $\begin{array}{l}\text { Corrupt } \\
\text { legislators }\end{array}$ & $\begin{array}{l}\text { Single comprehensive } \\
\text { legal framework; } \\
\text { sanctions }\end{array}$ & $\begin{array}{l}\text { Poor financial } \\
\text { incentive to } \\
\text { whistleblowers }\end{array}$ & $\begin{array}{l}\text { Competitive rewards; } \\
\text { simplified claim } \\
\text { process }\end{array}$ & \\
\hline \multirow[t]{2}{*}{ Judiciary } & Weak judiciary & $\begin{array}{l}\text { Empowerment and } \\
\text { independence }\end{array}$ & $\begin{array}{l}\text { High risk to } \\
\text { whistleblowers, } \\
\text { including } \\
\text { assassination }\end{array}$ & $\begin{array}{l}\text { Protection against } \\
\text { retaliation } \\
\text { Respecting the } \\
\text { anonymity of } \\
\text { whistleblowers }\end{array}$ & \\
\hline & $\begin{array}{l}\text { Corrupt judges } \\
\text { and prosecutors }\end{array}$ & $\begin{array}{l}\text { Dismissal, termination } \\
\text { and retirement }\end{array}$ & $\begin{array}{l}\text { Technological } \\
\text { challenges }\end{array}$ & $\begin{array}{l}\text { Quality compliance } \\
\text { systems; investment } \\
\text { in modern technology } \\
\text { such as SMART, } \\
\text { mobile apps, data } \\
\text { mining }\end{array}$ & \\
\hline \multirow[t]{6}{*}{$\begin{array}{l}\text { Private sector } \\
\text { / civil society }\end{array}$} & $\begin{array}{l}\text { Corrupt } \\
\text { government } \\
\text { contractors }\end{array}$ & $\begin{array}{l}\text { Process improvement } \\
\text { and enhanced } \\
\text { monitoring } \\
\text { mechanisms; open } \\
\text { bidding }\end{array}$ & $\begin{array}{l}\text { Poor leadership } \\
\text { and organization } \\
\text { structure }\end{array}$ & $\begin{array}{l}\text { Reorganization and } \\
\text { empowerment }\end{array}$ & \\
\hline & $\begin{array}{l}\text { Lack of auditor } \\
\text { independence }\end{array}$ & Auditor independence & $\begin{array}{l}\text { High risk to } \\
\text { investigators }\end{array}$ & $\begin{array}{l}\text { Investigator } \\
\text { protection }\end{array}$ & \\
\hline & $\begin{array}{l}\text { Unethical } \\
\text { auditors and } \\
\text { accountants }\end{array}$ & $\begin{array}{l}\text { Ethical principles and } \\
\text { code of conduct; strong } \\
\text { ethical professional } \\
\text { associations }\end{array}$ & $\begin{array}{l}\text { Corrupt } \\
\text { investigators }\end{array}$ & $\begin{array}{l}\text { Quality hire; certified } \\
\text { professionals }\end{array}$ & \\
\hline & $\begin{array}{l}\text { Lack of internal } \\
\text { policies that } \\
\text { encourage } \\
\text { whistleblowing }\end{array}$ & $\begin{array}{l}\text { Strong, transparent } \\
\text { and effective policies } \\
\text { for internal and } \\
\text { external reporting in } \\
\text { organizations }\end{array}$ & $\begin{array}{l}\text { Understaffing of } \\
\text { investigators }\end{array}$ & $\begin{array}{l}\text { Enhanced budget; } \\
\text { capacity building; } \\
\text { retention programs }\end{array}$ & \\
\hline & $\begin{array}{l}\text { Tolerance for } \\
\text { corruption }\end{array}$ & $\begin{array}{l}\text { organizations } \\
\text { Public support for } \\
\text { whistleblowing; public } \\
\text { clamour for change }\end{array}$ & $\begin{array}{l}\text { Inexperienced } \\
\text { investigators }\end{array}$ & $\begin{array}{l}\text { Training; } \\
\text { engagement of } \\
\text { certified forensic } \\
\text { accountants and } \\
\text { lawyers }\end{array}$ & $\begin{array}{r}\text { Table 8. } \\
\text { Challenges and } \\
\text { opportunities for } \\
\text { effective } \\
\text { whistleblowing in a } \\
\text { developing democracy: }\end{array}$ \\
\hline & & & & (continued) & \\
\hline
\end{tabular}


AAAJ 33,6

\section{8}

Institutional environment

Cocio-cultural

Socio-cultural

Entrenched
corruption

Tribalism, nepotism and fanaticism
Program institutionalization

Opportunities Challenges $\quad$ Opportunities

Overlay of culture on reformed institutional environment

Conflicts over professional jurisdiction Education; national Low legitimacy unity and equity; transparency; fairness
Broad and clear mandates

Muddling through, learning by doing, being creative, adapting incrementally; creating and sustaining trust Bridging the gap between legal and communal logics

$\begin{array}{lll}\text { Informal rules and } & \text { Enforcement of formal } \\ \text { regulations (this is } & \text { rules; effective } \\ \text { how we do it here) } & \text { leadership }\end{array}$

Informal rules and Enforcement of formal regulations (this is Partly free press;

Source(s): Authors (2019)

Table 8.

Prior studies have focused on the institutional environment (political, legislative, judicial and socio-cultural) and/or external controls (e.g. auditors, rating agencies, market regulators) to explain the importance of institutional contexts (Scott, 2014; Gabbioneta et al., 2013). Our study suggests ways in which institutionalization of a culture-based anticorruption accountability mechanism can be used to curb corruption. This study proposes that the effectiveness of anticorruption interventions such as whistleblowing depends on both an enabling institutional environment and program institutionalization (Scott, 2014; Zucker, 1983), and these two factors are mutually constitutive.

The policy implications are that in implementing whistleblowing policies, government and anticorruption agencies need to: (1) adequately protect whistleblowers and integrate appropriate financial incentives into the enactment and implementation of whistleblowing, (2) provide an enabling indigenous culture-based institutional environment that holds political leaders and corporate executives accountable, and (3) increase program awareness and adequately engage citizens to obtain a social license or socio-cultural legitimacy and institutionalize the intervention.

Our study has some limitations. First, we obtained evidence from a purposeful sample in Nigeria and considered the country's multicultural mosaic in the design and conduct of our study. While this construction has the potential to generate positive outcomes for whistleblowing agenda in the country, it may also have the unintended consequence of limiting the generalizability of the study to other countries given Nigeria's peculiarities. Second, we surveyed only urban dwellers because we wanted to reach the segment of the population with high literacy rates. A future study may expand its sample size to include the entire country. Again, examining public opinions in other developing countries may help to present a more comprehensive picture. Third, we recognize that NGOs have played major roles in fighting corruption in Nigeria, but we did not survey them for this study. Last, this study did not seek evidence on any other mechanism to overcome corrupt government 
officials or any resistance from the government to implement such an accountability mechanism we propose [14]. These are important areas for further research. Nonetheless, we are confident that the citizens' input presented here, and suggestions offered advance the accountability literature and may be beneficial to accountable institutions in Nigeria.

\section{Notes}

1. These include, the Economic and Financial Crimes Commission (EFCC), the Independent Corrupt Practices and Other Related Offences Commission (ICPC), the Code of Conduct Bureau (CCB), the Code of Conduct Tribunal (CCT).

2. We wish to thank two anonymous reviewers for useful suggestions on our methodology.

3. Approximately $23 \%$ of respondents identified as students. We surveyed urban dwellers, where adult literacy level is significantly higher at 73.6 versus $49.5 \%$ in rural areas (National Bureau of Statistic, 2010), and a respondent must have at least a college diploma or is attending a postsecondary institution.

4. The authors were able to administer surveys in four of six geopolitical zones due to safety concerns. At the time of data collection, Southerners (specifically Igbos) living in the North were given a 90days ultimatum by a Coalition of Northern Groups (CNG) to leave the North or face imminent danger. From the Nigerian cities listed on the World Urban Areas report by Demographia (2016), the four biggest cities were selected, subject to being either a state capital or the federal capital. Only one city was selected from each geopolitical zone. Specifically, the authors selected Abuja, Benin City, Enugu and Lagos

5. World Bank estimates that $50 \%$ of Nigerians were urban dwellers in 2017 (The World Bank Group, 2018).

6. NASS refers to the Federal Republic of Nigeria "National Assembly".

7. No or missing responses are as follows: purpose (5 per factor); obstacles (ministry understaffed 5 , EFCC understaffed 7, inexperienced regulators 5, politicians would undermine 6 , whistleblowing too risky 5, EFCC will become corrupt 5); incentives (5 per factor); and determinants of effective whistleblowing (education 6 , other factors 5 each).

8. Surprisingly, this is the second most common response besides the overwhelming percentage that see fighting corruption as very important. These findings seem to depict some interesting polarized perspectives.

9. Similar to the results for Table 2, some respondents see the determinants as not important.

10. We thank two anonymous reviewers for suggesting this approach.

11. Results available from authors on request.

12. Results available from authors on request.

13. Computed by authors using data from the Budget Office of the Federation - Federal Republic of Nigeria (2020).

14. We thank an anonymous reviewer for drawing our attention to this limitation.

\section{References}

Agbiboa, D.E. (2012), "Between corruption and development: the political economy of state robbery in Nigeria", Journal of Business Ethics, Vol. 108 No. 3, pp. 325-345.

Akinkugbe, O.D. (2018), "Informal networks of corruption: assessing the challenges for public sector whistleblowing in Nigeria", Jindal Global Law Review, Vol. 9 No. 1, pp. 11-28.

Aldrich, H.E. and Fiol, C.M. (1994), "Fools rush in? The institutional context of industry creation", Academy of Management Review, Vol. 19 No. 4, pp. 645-670. 
AAAJ 33,6

Alleyne, P., Hudaib, M. and Pike, R. (2013), "Towards a conceptual model of whistle-blowing intentions among external auditors", The British Accounting Review, Vol. 45 No. 1, pp. 10-23.

Alleyne, P., Hudaib, M. and Haniffa, R. (2018), "The moderating role of perceived organisational support in breaking the silence of public accountants", Journal of Business Ethics, Vol. 147 No. 3, pp. 509-527.

Ayamba, I.A. (2019), "Whistleblowing in a depraved Nigerian economy: challenges and prospects", International Journal of Social Science Studies, Vol. 7 No. 2, pp. 1-11.

Bakre, O.M. and Lauwo, S.G. (2016), "Privatisation and accountability in a 'crony capitalist' Nigerian state", Critical Perspectives on Accounting, Vol. 39, Complete, pp. 45-58.

Bakre, O.M., Lauwo, S.G. and McCartney, S. (2017), "Western accounting reforms and accountability in wealth redistribution in patronage-based Nigerian society", Accounting, Auditing and Accountability Journal, Vol. 30 No. 6, pp. 1288-1308.

Bamidele, O., Olaniyan, A. and Ayodele, B. (2016), "Culture, corruption, and anticorruption struggles in Nigeria", Journal of Developing Societies, Vol. 32 No. 2, pp. 103-129.

Bougen, P.D., Young, J.J. and Cahill, E. (1999), "Accountants and the everyday: or what the papers said about the Irish accountant and tax evasion”, European Accounting Review, Vol. 8 No. 3, pp. 443-461.

Brennan, N. and Kelly, J. (2007), "A study of whistleblowing among trainee auditors", The British Accounting Review, Vol. 39 No. 1, pp. 61-87.

Budget Office of the Federation - Federal Republic of Nigeria (2020), "Budget documents", available at https://budgetoffice.gov.ng/index.php/resources/internal-resources/budget-documents (accessed 14 February 2020).

Callahan, E.S. and Collins, J.W. (1992), "Employee attitudes toward whistleblowing: management and public policy implications", Journal of Business Ethics, Vol. 11 No. 12, pp. 939-948.

Carson, L.D. and Prado, M.M. (2016), "Using institutional multiplicity to address corruption as a collective action problem: lessons from the Brazilian case", The Quarterly Review of Economics and Finance, Vol. 62, pp. 56-65.

Cordis, A.S. and Lambert, E.M. (2017), "Whistleblower laws and corporate fraud: evidence from the United States”, Accounting Forum, Vol. 41 No. 4, pp. 289-299.

Cortina, J.M. (1993), "What is coefficient alpha? An examination of theory and applications", Journal of Applied Psychology, Vol. 78 No. 1, p. 98.

Culiberg, B. and Mihelic, K.K. (2017), "The evolution of whistleblowing studies: a critical review and research Agenda", Journal of Business Ethics, Vol. 146 No. 4, pp. 787-803, doi: 10.1007/s10551016-3237-0.

Dacin, M.T., Goodstein, J. and Scott, W.R. (2002), "Institutional theory and institutional change: introduction to the special research forum”, Academy of Management Journal, Vol. 45 No. 1, pp. $45-57$.

Davies, A.C. (2001), Accountability: A Public Law Analysis of Government by Contract, Oxford University Press, New York.

De Maria, W. (1995), "Quarantining dissent: the queensland public sector ethics movement", Australian Journal of Public Administration, Vol. 54 No. 4, pp. 442-454.

Deephouse, D., Bundy, J., Tost, L. and Suchman, M. (2017), "Organizational legitimacy: six key questions", in Greenwood, R., Oliver, C., Lawrence, T. and Meyer, R. (Eds), The SAGE Handbook of Organizational Institutionalism, 2nd ed., Sage, 'Thousand Oaks CA.

Demographia (2016), "Demographia world urban areas", available at: http://www.demographia.com/ db-worldua.pdf (accessed 15 June 2017).

Denedo, M., Thomson, I. and Yonekura, A. (2017), "International advocacy NGOs, counter accounting, accountability and engagement", Accounting, Auditing and Accountability Journal, Vol. 30 No. 6, pp. 1309-1343. 
Dietz, T., Stern, P.C. and Guagnano, G.A. (1998), "Social structural and social psychological bases on environmental concern”, Environment and Behavior, Vol. 30 No. 4, pp. 450-471.

DiMaggio, P.J. and Powell, W.W. (1983), "The iron cage revisited: institutional isomorphism and collective rationality in organizational fields", American Sociological Review Vol. 48 No. 2, pp. 147-160.

Dungan, J., Waytz, A. and Young, L. (2015), "The psychology of whistleblowing”, Current Opinion in Psychology, Vol. 6, pp. 129-133.

Dworkin, J.P. and Baucus, M.S. (1998), "Internal vs. External whistleblowers: a comparison of whistleblowing processes", Journal of Business Ethics Vol. 17 No. 12, pp. 1281-1298.

Dye, K.M. and Stapenhurst, R. (1998), Pillars of Integrity: The Importance of Supreme Audit Institutions in Curbing Corruption, Economic Development Institute of the World Bank, Washington, DC, available at: academia.edu (accessed 14 February 2020).

Ekeh, P. (1975), "Colonialism and the two publics in Africa: a theoretical statement", Comparative Journal of Society and History, Vol. 17 No. 1, pp. 91-112.

Elliston, F.A. (1982), "Civil disobedience and whistleblowing: a comparative appraisal of two forms of dissent", Journal of Business Ethics, Vol. 1 No. 1, pp. 23-28.

Everett, J. (2004), "Exploring (false) dualisms for environmental accounting praxis", Critical Perspectives on Accounting, Vol. 15 No. 8, pp. 1061-1084.

Everett, J., Neu, D. and Rahaman, A.S. (2007), “Accounting and the global fight against corruption", Accounting, Organizations and Society, Vol. 32 No. 6, pp. 513-542.

Falana, F. (2018), "The role of whistle-blowers in the fight against corruption in Nigeria", available at: http://www.africmil.org/the-role-of-whistle-blowers-in-the-fight-against-corruption-in-nigeria (accessed 3 June 2019).

Farag, D.M. and Dworkin, T.M. (2016), "A taxing process: whistleblowing under the IRS reward program”, Southern Law Journal, Vol. 26 No. 1, p. 19.

Federal Ministry of Finance (2017), "FG confirms first payments to Whistleblowers", available at: http://www.finance.gov.ng/index.php/resources/news-media/news-archive/294-fg-confirms-firstpayments-to-whistleblowers (accessed 18 September 2017).

Federal Republic of Nigeria National Assembly (2017), "Senate passes into law consume protection, witness protection and Federal Road Authority Bills", available at: http://nass.gov.ng/news/ item/508 (accessed 9 September 2017).

Foegle, J.P. (2015), Endorsing Whistleblowing as a Democratic Accountability Mechanism: Benefits of a Human-Rights Based Approach to a Whistleblowing Protection, Submission to the UN Special Rapporteur on the Protection of Sources and Whistleblowers, available at: https:/www.ohchr. org/Documents/Issues/Opinion/Protection/JeanPhilippeFoegle.pdf (accessed 3 June 2019).

Gabbioneta, C., Greenwood, R., Mazzola, P. and Minoja, M. (2013), "The influence of the institutional context on corporate illegality", Accounting, Organizations and Society, Vol. 38 Nos 6-7, pp. 484-504.

Goddard, A., Assad, M., Issa, S., Malagila, J. and Mkasiwa, T.A. (2016), "The two publics and institutional theory - a study of public sector accounting in Tanzania", Critical Perspectives on Accounting, Vol. 40, Complete, pp. 8-25.

Granovetter, M. (1992), "Economic institutions as social constructions: a framework for analysis", ActaSociologica, Vol. 35 No. 1, pp. 3-11.

Greenwood, R., Raynard, M., Kodeih, F., Micelotta, E.R. and Lounsbury, M. (2011), "Institutional complexity and organizational responses", Academy of Management Annals, Vol. 5 No. 1, pp. 317-371.

Grindle, M.S. (2004), "Good enough governance: poverty reduction and reform in developing countries”, Governance, Vol. 17 No. 4, pp. 525-548. 
Harrison, G. (2005), "The world bank, governance and theories of political action in Africa", The British Journal of Politics and International Relations, Vol. 7 No. 2, pp. 240-260.

Hoffmann, L.K. and Patel, R.N. (2017), Collective Action on Corruption in Nigeria: A Social Norms Approach to Connecting Society and Institutions, Chatham House, London.

Ijewereme, O.B. (2015), "Anatomy of corruption in the Nigerian public sector: theoretical perspectives and some empirical explanations", SAGE Open, Vol. 5 No. 2, pp. 1-16.

Inyang, W. (2016), "Under-funding the supreme audit institution amidst the rising unauthorized extrabudgetary expenditures in Nigeria: is deliberate under-funding a fraud-concealing device?", Research Paper Series, Research Journal of Finance and Accounting, Vol. 7 No. 16.

Iyoha, F.O. and Oyerinde, D. (2010), "Accounting infrastructure and accountability in the management of public expenditure in developing countries: a focus on Nigeria", Critical Perspectives on Accounting, Vol. 21 No. 5, pp. 361-373.

Kaptein, M. (2011), "From inaction to external whistleblowing: the influence of the ethical culture of organizations on employee responses to observed wrongdoing”, Journal of Business Ethics, Vol. 98 No. 3, pp. 513-530.

Kinder, D.R. and Sears, D.O. (1985), "Public opinion and political action”, in: Lindzey, G. and Aronson, E. (Eds), The Handbook of Social Psychology, 3rd ed., Random House, New York, Vol. II, pp. 659-741.

Kreander, N. and McPhail, K. (2019), "State investments and human rights? The case of the Norwegian government pension fund global", Accounting, Auditing and Accountability Journal, Vol. 32 No. 6, pp. 1742-1770.

Latan, H., Charbel Jose, C.J. and Ana Beatriz Lopes de, S. (2018), "Whistleblowing triangle': framework and empirical evidence", Journal of Business Ethics, pp. 1-16.

Lavallée, E. and Roubaud, F. (2019) "Corruption in the informal sector: evidence from WestAfrica", The Journal of Development Studies, Vol. 55 No. 6, pp. 1067-1080.

Lawrence, T.B. and Suddaby, R. (2006), "Institutions and institutional work", in Clegg, S.R., Hardy, C., Lawrence, T.B. and Nord, W.R. (Eds), The Sage Handbook of Organization Studies, Sage, London, pp. 215-254.

Lawrence, T.B., Suddaby, R. and Leca, B. (2009), Institutional Work: Actors and Agency in Institutional Studies of Organizations, Cambridge University Press, Cambridge.

Lee, G. and Xiao, X. (2018), "Whistleblowing on accounting-related misconduct: a synthesis of the literature", Journal of Accounting Literature, Vol. 41, Complete, pp. 22-46.

Liyanarachchi, G. and Newdick, C. (2009), "The impact of moral reasoning and retaliation on whistleblowing: New Zealand evidence”, Journal of Business Ethics, Vol. 89 No. 1, pp. 37-57.

Loyens, K. (2013), “Towards a custom-made whistleblowing policy. using grid-group cultural theory to match policy measures to different styles of peer reporting", Journal of Business Ethics,Vol. 114 No. 2, pp. 239-249.

Luo, Y. (2005), "An organizational perspective on corruption”, Management and Organization Review, Vol. 1 No. 1, pp. 119-154.

MacNab, B., Brislin, R., Worthley, R., Galperin, B.L., Jenner, S., Lituchy, T.R. and Bess, D. (2007), "Culture and ethics management: whistle-blowing and internal reporting within a NAFTA country context", International Journal of Cross Cultural Management, Vol. 7 No. 1 , pp. 5-28.

Mannion, R., Blenkinsopp, J., Powell, M., McHale, J., Millar, R., Snowden, N. and Davies, H. (2018), "Understanding the knowledge gaps in whistleblowing and speaking up in health care: narrative reviews of the research literature and formal inquiries, a legal analysis and stakeholder interviews", Health Services and Delivery Research, Vol. 6 No. 30 , pp. 1-31. 
MainaWaweru, N., Hoque, Z. and Uliana, E. (2004), "Management accounting change in South Africa: case studies from retail services", Accounting, Auditing and Accountability Journal, Vol. 17 No. 5 , pp. 675-704.

Maroun, W. and Atkins, J. (2014), "Whistle-blowing by external auditors in South Africa", Accounting, Auditing and Accountability Journal, Vol. 27 No. 5, pp. 834-862.

Whistleblowing to curb corruption and fraud

Maroun, W. and Solomon, J. (2014), "Whistle-blowing by external auditors: seeking legitimacy for the South African audit profession?”, Accounting Forum, Vol. 38 No. 2, pp. 109-121.

Mbago, M., MpeeraNtayi, J. and Mutebi, H. (2018), "Does legitimacy matter in whistleblowing intentions?", International Journal of Law and Management, Vol. 60 No. 2, pp. 627-645.

Mbaku, J. (2016), "International law and the fight against bureaucratic corruption in Africa", Arizona Journal of International and Comparative Law Vol. 33 No. 3, pp. 661-764.

McPherson, C.M. and Sauder, M. (2013), "Logics in action: managing institutional complexity in a drug court”, Administrative Science Quarterly, Vol. 58 No. 2, pp. 165-196.

Meyer, J.W. and Rowan, B. (1977), "Institutionalized organizations: formal structure as myth and ceremony", American Journal of Sociology, Vol. 83 No. 2, pp. 340-363.

Miceli, M.P. and Near, J.P. (1988), "Individual and situational correlates of whistleblowing", Personnel Psychology, Vol. 41 No. 2, pp. 267-281.

Miceli, M.P., Near, J.P., Rehg, H.T. and Van Scooter, J.R. (2012), "Predicting employee reactions to perceived organizational wrongdoing: demoralization, justice, proactive personality, and whistleblowing", Human Relations, Vol. 65 No. 8, pp. 923-954.

Ministry of Finance (2016), "FMF - WHISTLE BLOWING frequently asked questions (FAQs)", available at: http://whistle.finance.gov.ng/Pages/default.aspx (accessed 12 October 2017).

Modell, S., Vinnari, E. and Lukka, K. (2017), "On the virtues and vices of combining theories: the case of institutional and actor-network theories in accounting research", Accounting, Organizations and Society, Vol. 60 Complete, pp. 62-78.

Morestin, F. (2012), A Framework for Analyzing Public Policies: Practical Guide, Government of Quebec, available at: http://www.ncchpp.ca/docs/guide_framework_analyzing_policies_en.pdf (accessed 14 February 2020).

Misangyi, V.F., Weaver, G.R. and Elms, H. (2008), "Ending corruption: the interplay among institutional logics, resources and institutional entrepreneurs", Academy of Management Review, Vol. 33 No. 3, pp. 750-770.

Near, J. and Miceli, M. (1996), "Whistleblowing: myth and reality", Journal of Management, Vol. 12 No. 3, pp. 507-526.

Near, J.P., Dworkin, T.M. and Miceli, M.P. (1993), "Explaining the whistleblowing process: suggestions from power theory and justice theory”, Organization Science, Vol. 4 No. 3, pp. 393-411.

Nielsen, R.P. (2013), "Whistleblowing methods for navigating within and helping reform regulatory institutions", Journal of Business Ethics, Vol. 112 No. 3, pp. 385-395.

North, D. (1990), Institutions, Institutional Change, and Economic Performance, University Press, Cambridge.

Nyamori, R.O., Abdul-Rahaman, A. and Grant, S. (2017), "Accounting, auditing and accountability research in Africa", Accounting, Auditing and Accountability Journal, Vol. 30 No. 6, pp. 1206-1229.

Ogungbamila, B. (2014), "Whistleblowing and anti-corruption crusade: evidence from Nigeria", Canadian Social Science, Vol. 10 No. 4, pp. 145-154.

Okafor, O.N., Opara, M. and Adebisi, F. (2020), "Whistleblowing and the fight against corruption and fraud in Nigeria: perceptions of anti-corruption agents (ACAs)", Crime, Law and Social Change, Vol. 73 No. 2, pp. 115-132. 
AAAJ 33,6

Opara, M. and Rouse, P. (2019), "The perceived efficacy of public-private partnerships: a study from Canada”, Critical Perspectives on Accounting, Vol. 58, Complete, pp. 77-99.

Park, H., Bjørkelo, B. and Blenkinsopp, J. (2018), "External whistleblowers' experiences of workplace bullying by superiors and colleagues", Journal of Business Ethics, pp. 1-11, doi: 10.1007/s10551018-3936-9.

Patton, M.Q. (2015), Qualitative Research and Evaluation Methods: Integrating Theory and Practice, 4th ed., Sage, Thousand Oaks, CA.

Pillay, S. and Kluvers, R. (2014), "An institutional theory perspective on corruption: the case of a developing democracy", Financial Accountability and Management, Vol. 30 No. 1, pp. 95-119.

PricewaterhouseCoopers (2016), "Impact of corruption on Nigeria's economy", available at: https://www. pwc.com/ng/en/assets/pdf/impact-of-corruption-on-nigerias-economy.pdf (accessed 24 June 2017).

Rahaman, A.S. (2009), "Independent financial auditing and the crusade against government sector financial mismanagement in Ghana”, Qualitative Research in Accounting and Management, Vol. 6 No. 4, pp. 224-246.

Rahaman, A.S. (2010), "Critical accounting research in Africa: whence and whither", Critical Perspectives on Accounting, Vol. 21 No. 5, pp. 420-427.

Reay, T. and Hinings, C.R. (2009), "Managing the rivalry of competing institutional logics", Organization Studies, Vol. 30 No. 6, pp. 629-652.

Reckers-Sauciuc, A. and Lowe, D.J. (2010), "The influence of dispositional affect on whistleblowing", Advances in Accounting, Vol. 26 No. 2, pp. 259-269.

Rothstein, B. (2011), The Quality of Government: Corruption, Social Trust, and Inequality in International Perspective, University of Chicago Press, Chicago.

Rhodes, E., Axsen, J. and Jaccard, M. (2017), "Exploring citizen support for different types of climate policy", Ecological Economics, Vol. 137 Complete, pp. 56-69.

Scott, W.R. (2014), Institutions and Organizations: Ideas and Interests, Sage Publications, Thousand Oaks, California.

Seifert, D., Sweeney, J., Joiremen, J. and Thorton, J. (2010), “The influence of organizational justice on accountant whistleblowing", Accounting, Organization and Society, Vol. 35 No. 7, pp. 707-717.

Shwom, R., Bidwell, D., Dan, A. and Dietz, T. (2010), "Understanding US public support for domestic climate change policies", Global Environmental Change, Vol. 20 No. 3, pp. 472-482.

Sims, R.L. and Keenan, J.P. (1998), "Predictors of external whistleblowing: organizational and intrapersonal variables", Journal of Business Ethics, Vol. 17 No. 4, pp. 411-421.

Smith, D.J. (2007), A Culture of Corruption: Everyday Deception and Popular Discontent in Nigeria, Princeton University Press, Princeton, NJ.

Smith, D.J. (2010), "Corruption, NGOs, and development in Nigeria", Third World Quarterly, Vol. 31 No. 2, pp. 243-258, doi: 10.1080/01436591003711975.

Smith, D.J. (2018), "Corruption and 'culture' in anthropology and in Nigeria", Current Anthropology, Vol. 59 No. S18, pp. S83-S91.

Smith, W.K. and Tracey, P. (2016), "Institutional complexity and paradox theory: complementarities of competing demands", Strategic Organization, Vol. 14 No. 4, pp. 455-466.

Stolowy, H., Gendron, Y., Moll, J. and Paugam (2019), "Building the legitimacy of whistleblowers: a multi-case discourse analysis", Contemporary Accounting Research, Vol. 36 No. 1, pp. 7-49.

Sulu-Gambari, W., Stafford, A. and Stapleton, P. (2018), "Public accountability reform in a Nigerian ministry", Qualitative Research in Accounting and Management, Vol. 15 No. 4, pp. 485-509.

Suyatno, B., Armstrong, A. and Thomas, K. (2015), "Whistleblowing and the Indonesian tax department: a framework for analysis", Journal of Business Systems, Governance and Ethics, Vol. 10 No. 3, pp. 21-33. 
Terry, M.D. and Baucus, M.S. (1998), "Internal vs. external whistleblowers: a comparison of Whistleblowing whistleblowing processes", Journal of Business Ethics, Vol. 17 No. 12, pp. 1281-1298.

The Heritage Foundation (2019), "2019 Index of economic freedom”, available at: https://www. heritage.org/index/country/nigeria\#government-size (accessed 21 November 2019).

The World Bank Group (2018), "Urban population (\% of total) the united Nations population divisions world urbanization prospects", available at: https://data.worldbank.org/indicator/SP.URB. TOTL.IN.ZS?locations =NG (accessed 23 September 2018).

Thornton, P.H. and Ocasio, W. (2008), "Institutional logics", in Greenwood, R., Oliver, C., Sahlin, K. and to curb corruption and fraud Suddaby, R. (Eds), The Sage Handbook of Organizational Institutionalism, Sage, Los Angeles, pp. 99-129.

Thornton, P.H., Ocasio, W. and Lounsbury, M. (2012), "The Institutional Logics Perspective A New Approach to Culture, Structure, and Process, Oxford University Press, Oxford.

Tolbert, P.S. and Zucker, L.G. (1996), "The institutionalization of institutional theory”, in Clegg, S.R., Hardy, C. and Nord, W.R. (Eds), Handbook of Organisational Studies, Sage Publications, London.

Taylor, E.Z. and Curtis, M.B. (2010), "An examination of the layers of workplace influences in ethical judgments: whistleblowing likelihood and perseverance in public accounting", Journal of Business Ethics, Vol. 93 No. 1, pp. 21-37.

Transparency Intern ational (2013), "International principles for whistleblower legislation", available at: https://www.transparency.org/whatwedo/publication/international_principles_for_whistle blower_legislation (accessed 15 November 2019).

Transparency International (2018), “Corruption perceptions Index 2017”, available at: https://www. transparency.org/news/feature/corruption_perceptions_index_2017\#table (accessed 28 April 2018).

Transparency International (2019), "Corruption perceptions Index 2018", available at: https://www. transparency.org/news/feature/cpi2018-subsaharan-africa-regional-analysis (accessed 4 June 2019).

United Nations (2019), "Goal 16: promote just, peaceful and inclusive societies", available at: https:// www.un.org/sustainabledevelopment/peace-justice/ (accessed 21 November 2019).

United Nations Office on Drugs and Crime (2017), "Corruption in Nigeria Bribery: public experience and response", available at: https://www.unodc.org/unodc/en/frontpage/2017/August/corruptionin-nigeria-survey-reveals-far-reaching-impact.html (accessed 3 June 2019).

United Nations Office on Drugs and Crime (2019), "Corruption in Nigeria: patterns and trends", available at: https://www.unodc.org/documents/nigeria/Corruption_Survey_2019.pdf (accessed 12 February 2019).

Ursachi, G., Horodnic, I.A. and Zait, A. (2015), "How reliable are measurement scales? External factors with indirect influence on reliability estimators", Procedia Economics and Finance, Vol. 20 No. 15 , pp. 679-686.

Ugur, M. and Dasgupta, N. (2011), Evidence of the Economic Growth Impacts of Corruption in LowIncome Countries and beyond: A Systematic Review, EPPI-Centre, Social Science Research Unit, Institute of Education, University of London, London, available at: https:/eppi.ioe.ac.uk/cms/ LinkClick.aspx?fileticket $=$ wrCtuggnIQ\%3D\&tabid $=3108 \&$ mid $=5787$ (accessed 1 October 2018).

Zucker, L. (1983), "Organizations as institutions", in Bacharach, S. (Ed.), Research in Sociology of Organizations, JAI Press, Greenwich, CT, pp. 1-47.

\section{Further reading}

Fligstein, N. and McAdam, D. (2011), "Toward a general theory of strategic action fields", Sociological Theory, Vol. 29 No. 1, pp. 1-26.

Marquis, C. and Lounsbury, M. (2007), "Vive la resistance: competing logics and the consolidation of U.S. community banking", Academy of Management Journal, Vol. 50 No. 4, pp. 799-820.

McCright, A.M. and Dunlap, R.E. (2010), “Anti-reflexivity”, Theory, Culture and Society, Vol. 27 Nos 2-3, pp. 100-133. 
AAAJ 33,6

Pache, A.C. and Santos, F. (2010), "When worlds collide: the internal dynamics of organizational responses to conflicting Institutional demands", Academy of Management Review, Vol. 35 No. 3, pp. $455-476$.

\section{Corresponding author}

Oliver Nnamdi Okafor can be contacted at: oliver.okafor@ryerson.ca

\section{6}

For instructions on how to order reprints of this article, please visit our website: www.emeraldgrouppublishing.com/licensing/reprints.htm Or contact us for further details: permissions@emeraldinsight.com 